\title{
Imitations of Christ in 17th-century France: Some attendant difficulties
}

\author{
Lecture in Modern Languages \\ read 22 May 2013 by \\ RICHARD PARISH
}

Abstract: The most important verse paraphrase of the Imitation of Christ in 17thcentury France was written by the dramatist Pierre Corneille. In his paratexts he discusses the difficulties he has encountered in the project, which expands on the original by including engravings, many of which illustrate episodes from the lives of saints. One such is Theodora, who is the subject of his closely contemporary martyr tragedy, Théodore. But here too he encountered difficulties, in the context of bienséance, from objections expressed to the prostitution with which the eponym is threatened. In a different idiom, the Jesuit priest Jean-Joseph Surin, seeing his role as exorcist as another kind of imitation of Christ, records his ordeal in two autobiographical works, one of which moves progressively into stylistic incoherence. Finally, Bossuet engages in the polemic surrounding a further possible implication of the term, in the form of the Catholic doctrine of the Real Presence.

Key words: Pierre Corneille, Jean-Joseph Surin, Bossuet, Imitation of Christ, verse paraphrase, martyr tragedy, exorcism, autobiography, polemic, Real Presence.

The Council of Trent (1545-63) was the single most influential event in the Roman Church in early-modern Europe, and the spectrum of (on occasion incompatible) developments which stemmed directly or indirectly from it, and which are usually gathered under the label of the Counter- (or Catholic) Reformation, marked France, traditionally 'la fille aînée de l'Église' ['the eldest daughter of the Church'], as much as any other predominantly Catholic society, over the ensuing century and a half. The tenets of priestly discipline, Christian education and sacramental devotion, as well as the means of integration of the laity into both more modest and more advanced forms of spiritual engagement, all inform the teaching and writing of prelates such as François de Sales, Bossuet or Fénelon; and even the polemics surrounding the theology 
of grace or the practice of auricular confession which pitted the Society of Jesus (Jesuits) against the adherents of Port-Royal (Jansenists) can be traced back to a common conciliar origin. But there is one feature which, more than any other, permeated the Catholic literary output of the French 17th century, and that is the emphasis on the life, teaching and death of Jesus, an emphasis that goes by the shorthand term of Christocentrism.

The text which begins my remarks, the Imitation of Christ, in fact dates from a much earlier period (it first came into circulation in 1418), but the reasons for its revived dissemination are not hard to reconcile with the Tridentine inheritance; and its most accomplished paraphrase was realised by one of the central figures of French neo-classicism, Pierre Corneille (1606-84). But it is by means of a freer interpretation of its title (which does not straightforwardly reflect the tenor of the work it introduces) that I have identified echoes of other writing and practice in the period, and so proceeded to consider three closely contemporary texts, representative in turn of three widely different literary traditions. The first, the same dramatist's Théodore vierge et martyre (1645-6), deals, as its title indicates, with the related subjects of virginity and martyrdom, but also provokes a debate that is centred around the compatibility of proto-Christian heroics with a progressively more rigorous (and rigorist) theatrical aesthetic. Secondly, the Jesuit Jean-Joseph Surin (1600-65), writing in the far less tightly codified sub-genre of spiritual autobiography, provides in a frequently chaotic prose narrative his own dramatic account of the practice of exorcism and of the associated ordeal of diabolic possession, to which he was subject. And finally JacquesBénigne Bossuet, bishop of Meaux (1627-1704), now reflecting the sacramental teaching directed at the priestly addressee of the last part of the Imitation, engages with one of the central doctrinal conflicts of the Reformation and its aftermath, that of the Real Presence, the question, in other words, of the nature (actual or figurative) of Christ's presence in the consecrated elements of the Eucharist.

In the 'Catalogue des écrivains français' drawn up as an appendix to his Siècle de Louis XIV, Voltaire comments succinctly and devastatingly of Pierre Corneille: 'On dit que sa traduction de l'Imitation de Jésus-Christ a été imprimée trente-deux fois: il est aussi difficile de le croire que de la lire une seule' ('It is said that his translation of the Imitation of Christ was reprinted thirty-two times: it is as difficult to believe that as it is to read it once'). ${ }^{1}$ But this was not the only difficulty encountered by those who tried variously to engage in imitations of Christ in 17th-century France, because Voltaire's swipe about the difficulties in reading also throws up questions concerning

1 'Catalogue de la plupart des écrivains français' in Le Siècle de Louis XIV in Voltaire (1957). All translations are my own. 
the difficulties about both writing and reading which occur in a range of texts in the period.

\section{PIERRE CORNEILLE: DE L'IMITATION DE JESUS-CHRIST (1651-6)²}

What Corneille was the first to recognise were certain of the difficulties he had himself experienced in translating the 15 th-century classic of devotio moderna, ${ }^{3}$ whose attribution, at the time, was a matter of controversy. There were no fewer than sixty-five separate versions published in France in the 17th century, ${ }^{4}$ either in French or in Latin, although the form of verse paraphrase was marked above all by the achievement of Pierre Corneille. He wrote, in the 1651 Au Lecteur, of his aim to produce 'une traduction fidèle, où j'ai tâché de conserver le caractère et la simplicité de l'auteur' ('a faithful translation in which I have sought to retain the character and simplicity of the author' $)^{5}$ - that is, presumably, Thomas à Kempis, to whose attribution he at least provisionally subscribes. ${ }^{6}$ His version, which appeared non-sequentially between 1651 and 1656, is divided, like the original, into four books, each subdivided into chapters, and of which the fourth is explicitly sub-titled: 'Du Très-Saint Sacrement de l'Autel' ('On the most holy sacrament of the altar'). Within the first three books, however, there exists a diversity of recurrent tonalities, with each of the interconnected sections given a specific devotional focus, broadly indicated by its title and, typically, describing a loose alternation between encouragement and abasement. The work is thus often repetitive, with the overall disposition of chapters functioning as a series of variations on a theme, rather than as an evolving project.

Reflecting these disjunctive and motivic dimensions, Corneille remarks in more

\footnotetext{
${ }^{2}$ De l'Imitation de Jésus-Christ, traduite et paraphrasée en vers français in Corneille (1984a).

${ }^{3}$ Couton stresses the centrality for devotio moderna of 'l'intimité personnelle entre l'âme et Dieu' ('personal intimacy between the soul and God') as opposed to 'la liturgie et [. . . les œuvres extérieures de dévotion' ('the liturgy and [. . .] external works of devotion') in Corneille (1984a), II, 1524.

${ }^{4}$ See A. Torri (1855), 429-84.

${ }^{5}$ Corneille (1984a), II, 791 and II, 803-4. Many, but not all, of the points made in the succession of introductory paratexts are included in the synthesising Avis au Lecteur which introduces the 1670 edition of the completed project. Where this is the case, I shall give both references. It would also appear from the 1651 piece that Corneille used the 1649 translation into Latin verse of the Benedictine Thomas Mesler as an intertext (Corneille (1984a), II, 792).

${ }^{6}$ In the first and third Au Lecteur of 1656, in Corneille (1984a), II, 800-1 and II, 805. The question also arises in the letters to the Père Boulart (see below, n. 27). Couton, however, remarks that 'entre le latin et la traduction de Corneille, la distance est souvent aussi grande qu'entre les apologues, brefs et secs, d'Ésope ou de Phèdre et les fables de La Fontaine' ('between the Latin and Corneille's translation, the distance is often just as great as that between the brief, dry apologues of Æsop or Phædrus and the Fables of La Fontaine') (Corneille (1984a), II, 1529).
} 
detail on the specific difficulties he has experienced in translating a devotional text into verse, identifying in particular 'le peu de disposition que les matières y ont à la poésie, le peu de liaison non seulement d'un chapitre avec l'autre, mais d'une période même avec celle qui la suit, et la quantité des redites qui s'y rencontrent' ('the little disposition which such matters have towards poetry, the absence of links not only between one chapter and the next but even between one period and the following one, and the amount of repetition which occurs'). ${ }^{7}$ To these he adds rather coyly his own 'peu de connaissance de la théologie, peu de pratique des sentiments de dévotion, et peu d'habitude à faire des vers d'ode et de stances' ('lack of knowledge of theology, lack of familiarity with pious feelings and lack of experience of writing verse in odes and stanzas'). ${ }^{8}$ And certainly in those sections in the third book devoted to the interplay of nature and grace, or in the sacramentally centred fourth book, we are on occasion made awkwardly aware of the difficulties of versifying theological speculation or Eucharistic doctrine. ${ }^{9}$

The emphasis throughout is on the vanity of the world, and on such virtues as humility, obedience, purity, simplicity and self-knowledge, in such a way as to promote spirituality and to relativise learning. ${ }^{10}$ There are thus many familiar devotional topoi: the longing for death; the embracing of divine folly; the punishment reserved for sins; the eschewing of the world; or purity of heart. In particular in the second book the focus moves to the difficulty of a true association with Christ's life: human consolations will be absent; ${ }^{11}$ many will want to dine with Christ, few will want to fast with him, ${ }^{12}$ and reluctance will be experienced in thanking him for rigours endured. ${ }^{13}$ It is, to a modern reader, and perhaps to a 17 th-century one as well, both practical, notably in certain of its modestly direct formulations of the individual's prayerful engagement with God, ${ }^{14}$ and anti-humanist, above all in its persistent deployment of a whole range of degrading images of humankind as dirt, dung, dust, mud, slime and so on, even if this disjunction is mitigated by the paradox that the soul is at the same time precious to God, so allowing the penitent to pray: 'Tire-moi de la fange où ma chute m'engage, | De ce bourbier épais arrache ton image; | Que par mon propre poids

\footnotetext{
${ }^{7}$ Au Lecteur of 1652, in Corneille (1984a), II, 793 and II, 804.

${ }^{8}$ Au Lecteur of 1652, in Corneille (1984a), II, 793. This modesty topos does not, however, recur in 1670.

${ }^{9}$ This is apparent in such devices as multiple inversion, complex rhyme schemes or, conversely, prosaism; thus, for example, Imitation, III, $54 \& 55$, or IV, 2.

${ }^{10}$ See, for example, Imitation, III, 43: 'Contre la vaine science du siècle, et de la vraie étude du Chrétien' ('Against the vain learning of the world, and of the true study of the Christian').

${ }^{11}$ Imitation, II, 9.

12 Imitation, II, 11.

${ }^{13}$ Imitation, II, 11.

${ }^{14}$ For example in the simple prayers proposed directly to the penitent by God in Imitation, III, 3; III, 15; III, 23; IV, 27.
} 


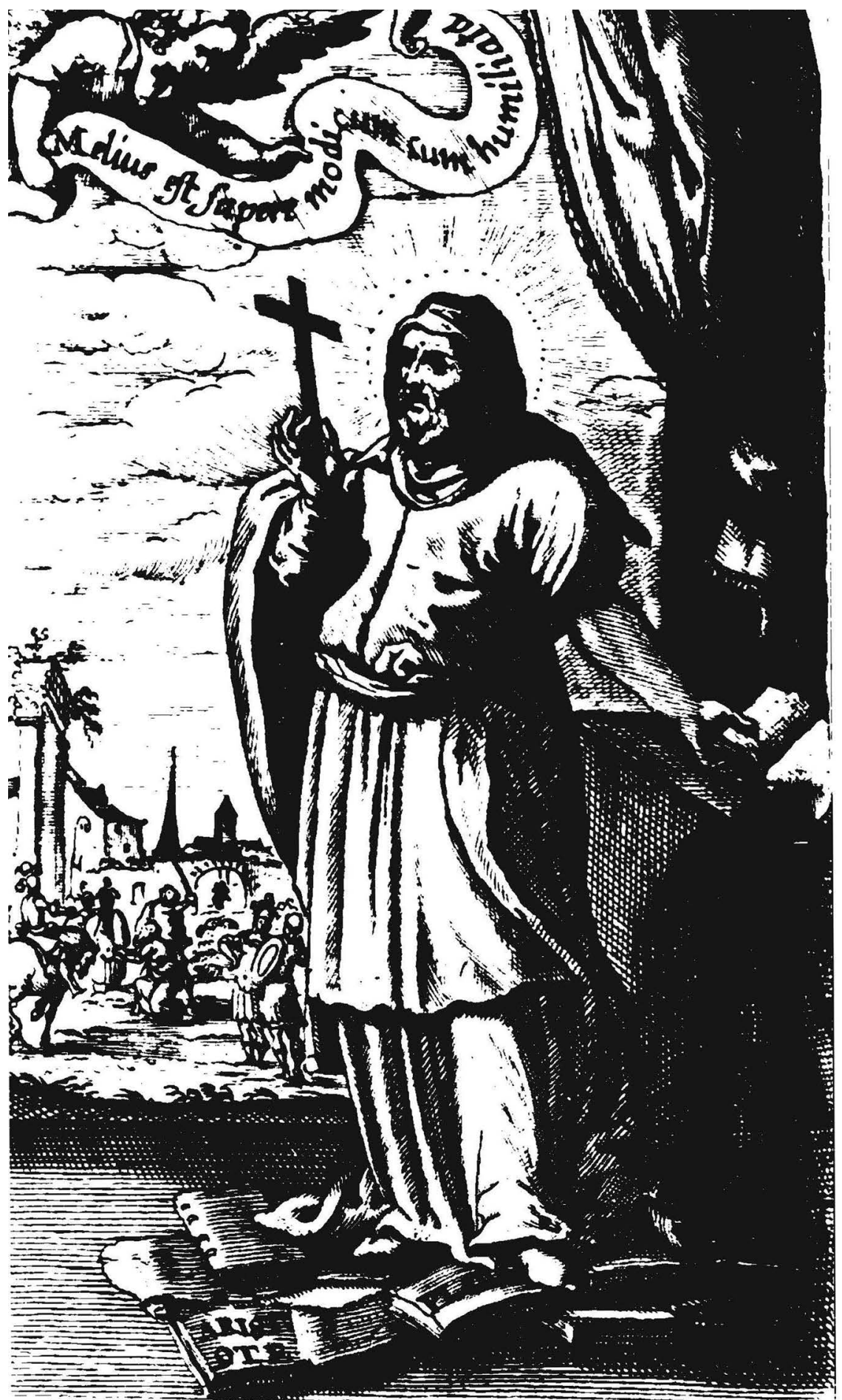

Figure 1. St Justin martyr foule aux pieds les livres des philosophes pour prendre l'Évangile et la Croix. 
je n'y reste enfoncé' ('Draw me out from this slime to which my fall condemns me. | Wrest your image from this thick mire | So that my own weight does not keep me entrapped within it'). ${ }^{15}$

In many ways too the tone, by turns sententious and lyrical, dogmatic and compassionate, corresponds to the common aims of Christian literature in the period of its translation to teach and to move. ${ }^{16}$ Yet, despite its title, the Imitation of Christ is far less intensely focused on the specifics of the life and passion of Jesus than many comparable examples of French devotional writing in the 17th century, even if a degree of physicality is occasionally present in some of its more extreme exhortations, thus: 'Sa Passion t'y [sur la terre] donne assez où t'arrêter; | Mais il faut, pour la bien goûter, | Affermir ta demeure au milieu de ses plaies' ('His Passion gives you enough reason [on earth] to pause; | But in order fully to savour it | You must establish your dwelling amidst his wounds'). ${ }^{17}$ Similarly, the end of the second book turns to a focus on the Cross, although here again with none of its visual or dramatic appeal exploited until the fourth, where Christ's words achieve the same degree of intensity as that present, for example, in Pascal's Mystère de Jésus: 'Vois comme tout nu sur la Croix, | Victime pure et volontaire, | Les deux bras étendus sur cet infâme bois, | Jadis pour tes péchés je m'offris à mon Père' ('See how, naked on the Cross, | A pure and willing victim, | With my two arms extended on this ignoble wood, I I once offered myself to my Father for your sins'). ${ }^{18}$ It is furthermore in this kind of shorter verse unit (here a metrically irregular septet), rather than in the protracted sequences of alexandrines, that the poetry of Corneille's Imitation de Jésus-Christ is particularly able to accord both variety and immediacy to the Latin source text.

Corneille's version extends to some 13,000 lines, and exploits a whole range of prosodic options and rhyme schemes, despite his professed unfamiliarity with 'odes and stanzas'. Readers who only know Corneille's tragedies will indeed be surprised to discover the metrical flexibility which he deploys, often to dramatic effect: ${ }^{19}$ and this is

${ }^{15}$ Imitation, III, 20. On the other hand, a pre-echo of the pragmatism of a St François de Sales (whose Introduction à la vie dévote was published in its final version in 1619) is briefly glimpsed in such chapter headings as: 'Tout esprit n'est pas propre aux mêmes exercices' ('Each spirit is not suited to the same exercises' (Imitation, I, 19)); or: 'Qu'il faut nous appliquer aux actions extérieures et ravalées, quand nous ne pouvons nous élever aux plus hautes' ('We should apply ourselves to external and humble actions, when we cannot aspire to anything higher' (Imitation, III, 51)).

16 This combination is also present within individual sections, thus Imitation, III, 33: 'De l'instabilité du cœur, et de l'intention finale qu'il faut dresser vers Dieu' ('Of the fickleness of the heart, and of the ultimate intention that must be directed towards God').

${ }^{17}$ Imitation, II, 1.

${ }^{18}$ Imitation, IV, 8. Cf. 'Je pensais à toi dans mon agonie, j'ai versé telles gouttes de sang pour toi' ('I was thinking of you in my agony, I shed certain drops of my blood for you') in Pascal (2004), 1317.

${ }^{19}$ Even including on occasion imparisyllabic verse, such as in the heptasyllabic 'Oraison pour faire le bon plaisir de Dieu' ('Mental prayer that will be pleasing to God' (Imitation, III, 15)) — one of several prayers proposed for particular circumstances. 
supported in turn by multiple forms of repetition and accumulation, as well as by a marked exploitation, in emphatic sequences, of the more familiar Cornelian forms of symmetry, such as anaphora or chiasmus. He also takes care, in particular in the third and fourth books, to contrast the believer's addresses to God (or apostrophe) with utterance attributed to Christ (or prosopopœia), with which they are frequently alternated. As a result, as he rather quaintly puts it in the Avis au Lecteur of 1670: '[J'ai] pris la liberté de changer la mesure de mes vers toutes les fois qu'il change de personnages, tant pour aider le lecteur à remarquer ce changement, que parce que je n'ai pas cru à propos que l'homme parlât le même langage que Dieu' ('II have] taken the liberty of changing the metre each time there is a change of speaker, both to help the reader to notice the transition, and because I did not think it seemly that mankind should speak the same language as God'), ${ }^{20}$ even if neither party seems to have a consistently preferred verse form. Biblical passages on the other hand are often less easily identifiable, and whereas (very rarely) a stanza is placed in quotation marks to denote its scriptural origin, the more common tendency is to iron out the junctions between the paraphrase of Thomas à Kempis and that of the Bible.

Imagery is relatively infrequent, with a preference for exemplification and enumeration taking its place. Thus, of the types of sudden death which might occur: 'L'un est percé d'un plomb funeste, | L'autre dans le jeu rend l'esprit, | Tel meurt étranglé dans son lit, | Et tel étouffé de la peste' ('One man is pierced by a deadly bullet, | Another gives up the ghost while at the gaming table; | Such and such dies strangled in his bed, | And another expires with the plague'). ${ }^{21}$ By virtue of the greater flexibility of the medium, however, further amplifications are frequently introduced, such as, when the original asserts that there is no creature so small and unworthy ('tam parva et vilis') that it does not reflect the goodness of God, Corneille embroiders: 'De sa pleine bonté rien ne parle à demi, | Et du vaste éléphant la masse épouvantable | Ne l'étale pas mieux que la moindre fourmi' ('Nothing speaks by halves of the extent of his goodness, | And the dreadful mass of the vast elephant | Shows it forth no better than the tiniest ant'). ${ }^{22}$ Such an impression is further reinforced when, for example, he evokes the Saints of the martyrology, and recalls how 'La faim, la soif, le froid, les oraisons, les veilles, | Les fatigues, la nudité, | Dans le sein de l'austérité | Ont produit toutes leurs merveilles' ('Hunger, thirst, cold, prayer, vigils, | Tiredness, nakedness, | In the midst

${ }^{20}$ Corneille (1984a), II, 806. In the 1658 Rouen quarto edition, the differentiation is underscored by a change of typeface: roman for Christ, and italics for humankind.

${ }^{21}$ Imitation, I, 23 ('Alius igne, alius ferro, alius latrocinio interiit'). Cf. the deadly sins (Imitation, I, 24); Christ's sufferings (Imitation, III, 18); the examination of conscience (Imitation, IV, 7).

${ }^{22}$ Imitation, II, 4 (' $\ldots$ non est creatura tam parva et vilis, quæ Dei bonitatem non repræsentur'). 
of austerity | Have worked all their wonders') ${ }^{23}$ (and these in the original are simply 'quam multas et graves tribulationes'). Overall, therefore, we have a poetic amplification of a paratactic and scripturally resonant source text. ${ }^{24}$

The fourth book, devoted entirely to the Blessed Sacrament, is thus different in its overall subject-matter from its predecessors, although not in many of the emphases which recur. Corneille indeed comments, in his progressive remarks on the business of translating, that he had hoped he might find it easier to render, but that, rather, 'je les [matières] y ai trouvées encore plus éloignées des ornements de la poésie, et les redites encore plus fréquentes' ('I found [the matters] I encountered there even further removed from the ornaments of poetry, and the repetitions even more frequent') ${ }^{25} \mathrm{It}$ is here too that the interlocutor most clearly takes on the identity of a priest, given his implied function of offering the Mass in several of the prosopopœic sections, or in the emphasis placed on the status of his acting in persona Christi. ${ }^{26}$

But what stands out above all in one contemporary edition of Corneille's paraphrase is the provision of 114 emblems and devises, to which, to judge from his correspondence, he accorded a particular importance. ${ }^{27}$ Each section of the work is thus provided by him with an engraving or corps ${ }^{28}$ accompanied by a French title and an (untranslated) Latin sententia or ame, with reference provided to the specific stanza in which it occurs, albeit with a varying degree of immediate applicability to the didactic purpose of the original chapter. In Corneille's words, '[leur] corps est toujours une action remarquable ou de Jésus-Christ, ou de la Vierge, ou d'un saint, ou de quelque personne illustre' ('their body is always a remarkable action of Christ, of the Virgin, of a saint or of some famous person'). ${ }^{29}$ They offer, as a result, a whole spectrum of vibrantly dramatic illustrations and models, ranging from the Old Testament, through pagan philosopher $\mathrm{s}^{30}$ and scenes from the life of Christ, to certain of the more exuberant of the Saints' lives (almost none of which figures explicitly in the urtext). ${ }^{31}$ Sometimes the scriptural and historical elements are syncretically conflated, such as

\footnotetext{
${ }^{23}$ Imitation, I, 18.

${ }^{24}$ Corneille himself amended the sub-title from 'traduite' to 'traduite et paraphrasée' (see Corneille (1984a), II, 1530).

${ }^{25}$ Second Au Lecteur of 1656, in Corneille (1984a), II, 800.

${ }^{26}$ Imitation, III, 5. Attention is also given to the priest's mouth and hands in Imitation, IV, 11.

${ }^{27}$ Corneille (1656). Corneille's letters to the Père Boulart, both on this matter and on the question of attribution, are included in Corneille (1984d), II, 1193-1202.

${ }^{28}$ These are attributed by Couton to François Chauveau and R. du Clos (Corneille (1984a), II, 1527, n. 1).

${ }^{29}$ Au Lecteur of 1653 in Corneille (1984a), II, 794.

${ }^{30}$ The work, however, casts a critical light on learning and curiosity, and in particular on secular philosophy, with one of the emblems showing St Justin trampling the works of Plato and Aristotle underfoot in favour of the Gospel and the Cross (Imitation, III, 7). This is expanded in Imitation, III, 43. See Figure 1.

${ }^{31}$ An exception would be that of St Lawrence in Imitation, II, 9.
} 


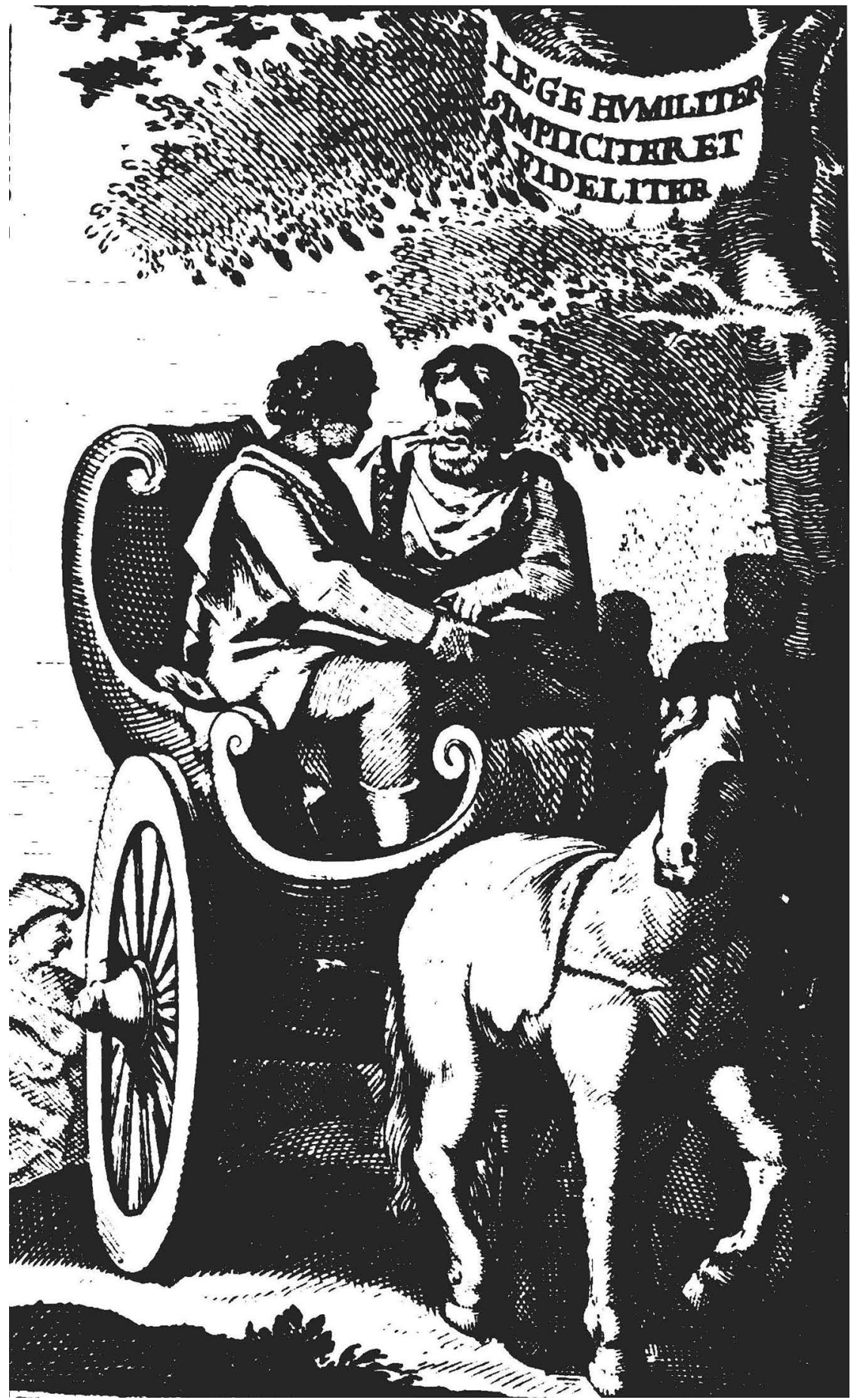

Figure 2. L'Eunuque de la Reine d'Éthiopie revenant de Jérusalem et lisant Isaïe dans son chariot est abordé par St Philippe qui lui explique ce prophète. 


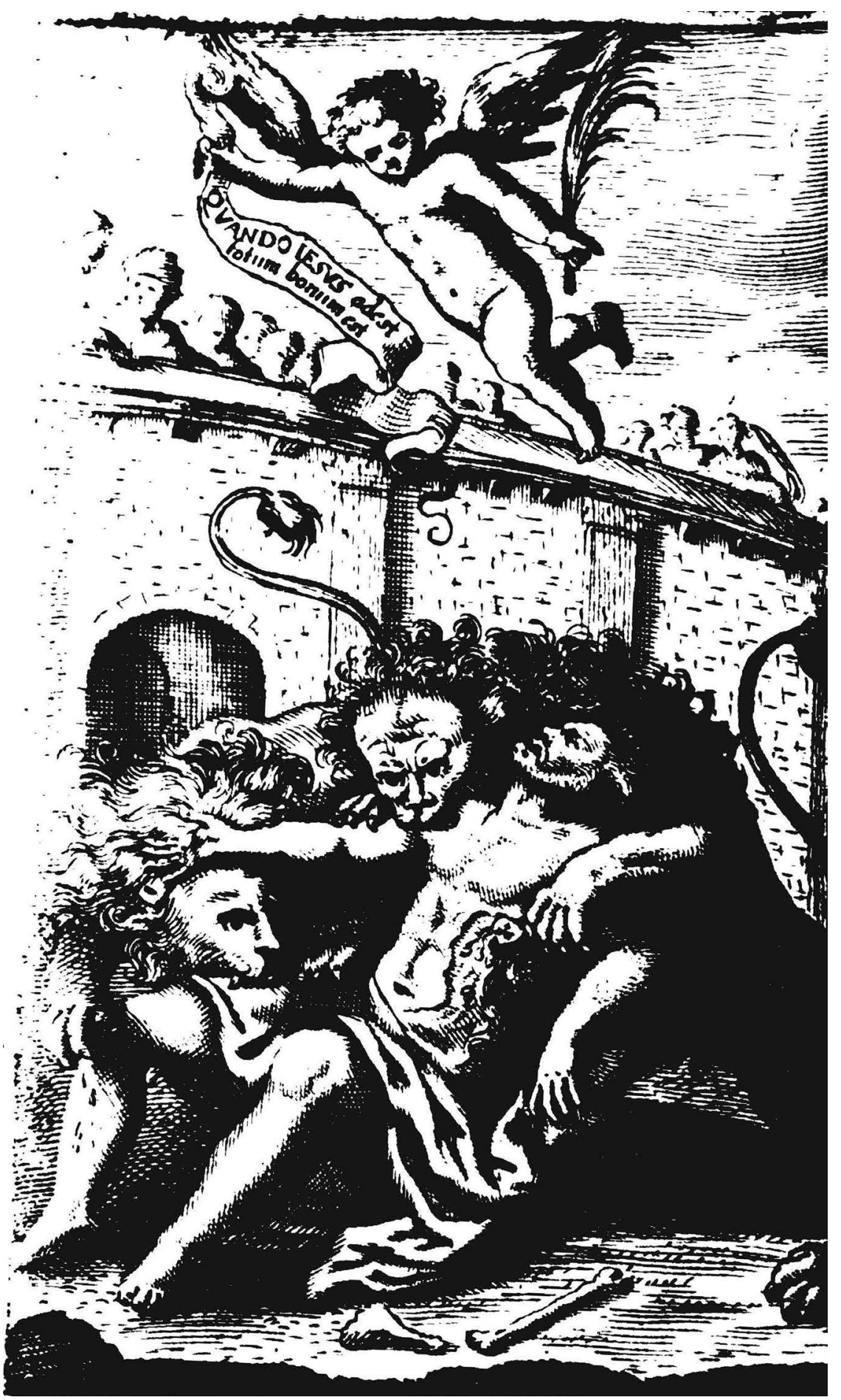

Figure 3. St Ignace martyr étant déchiré par les lions on voit le nom de JÉSUS gravé sur son cœur. 
when the eunuch of the queen of Ethiopia, returning from Jerusalem and reading the book of Isaiah in her chariot, is greeted by St Philip, who explains the prophet's words to him. ${ }^{32}$ Elsewhere we find St Ignatius of Antioch torn apart by lions, with the name of Christ engraved on his heart; ${ }^{33}$ St Ignatius Loyola jumping into a frozen pool to save a young man from $\sin ;{ }^{34}$ or St Eustache, having seen his wife abducted by a pirate, witnessing his children being carried off by a lion and a wolf. ${ }^{35}$ Most sensational of all are such sexually explicit incidents as that of the 6th-century St Mary the Penitent being converted by her uncle in the very place of her prostitution; ${ }^{36} \mathrm{St}$ Thaïs burning in a public square in Alexandria the precious belongings which she had acquired through $\sin ;{ }^{37}$ or St James the Hermit spending the rest of his life in penitence beside the body of a girl he had raped and murdered..$^{38}$

The origin of such emblems lies in all probability with Jesuit 'représentations sacrées', and so ultimately with the Spiritual Exercises of St Ignatius Loyola, although the spread of the practice seems to have crossed confessional divides. This is consistent with what Roland Barthes remarks in his essay on Ignatius, to the effect that the Jesuit practice of composition of place ('composition de lieu') turns episodes from the life of Christ (and by extension from the lives of his disciples) into what Barthes calls 'unités d'image', in the form of '[des] fragments tels qu'ils puissent être contenus dans un cadre et l'occuper entièrement' ('fragments which can be contained within a framework and occupy it entirely'), in this case iconographically. ${ }^{39}$ The tendency of these engravings is thus to vivify and make explicit the more general didactic tenor of the identified stanza. And indeed one emblem achieves a kind of mise en abyme, as Thomas à Kempis is portrayed converting several worldly people by reading the sententia which it depicts: 'Miser es ubicumque fueris, nisi au Deum te convertas' ('You will be unhappy wherever you are, unless you turn to God'). ${ }^{40}$

${ }^{32}$ Imitation, I, 5. See Figure 2.
${ }^{33}$ Imitation, II, 8. See Figure 3.

${ }^{34}$ Imitation, III, 9. Or, relatedly (and from a different religious order), a 14th-century Dominican mystic engraving the name of Jesus on his stomach with a penknife (Imitation, III, 10). See below, n. 39.

${ }^{35}$ Imitation, III, 20. More vernacular in idiom are the portrayals of such episodes as the living funeral arranged by the Emperor Charles $\mathrm{V}$ as a memento mori, in which he himself was a candle-bearer (Imitation, I, 23); or, more locally again, when St Mary Magdalene is portrayed appearing in the grotto of the Sainte Baume between Aix and Marseille (Imitation, I, 8).

${ }^{36}$ Imitation, III, 35. The identity of the saint in question is clarified in Corneille (1963a), 994, n. 63. See Figure 4.

${ }^{37}$ Imitation, III, 22. See Figure 5.

${ }^{38}$ Imitation, III, 52.

${ }^{39}$ Barthes (1971), 41-78: 55, 57. Cf. Spiritual Exercises in St Ignatius Loyola (2004), 47. The major difference with Ignatian teaching is that, in the original, all senses are applied to the exercise (see Spiritual Exercises in St Ignatius Loyola (2004), 66-70).

${ }^{40}$ Imitation, I, 22. This would also demonstrate Corneille's support for his authorship of the original. However, he is particularly careful to be even-handed in his portrayal of the religious orders in the emblems he chooses. See Corneille (1862-8a), Vol. VIII, x. See Figure 6. 


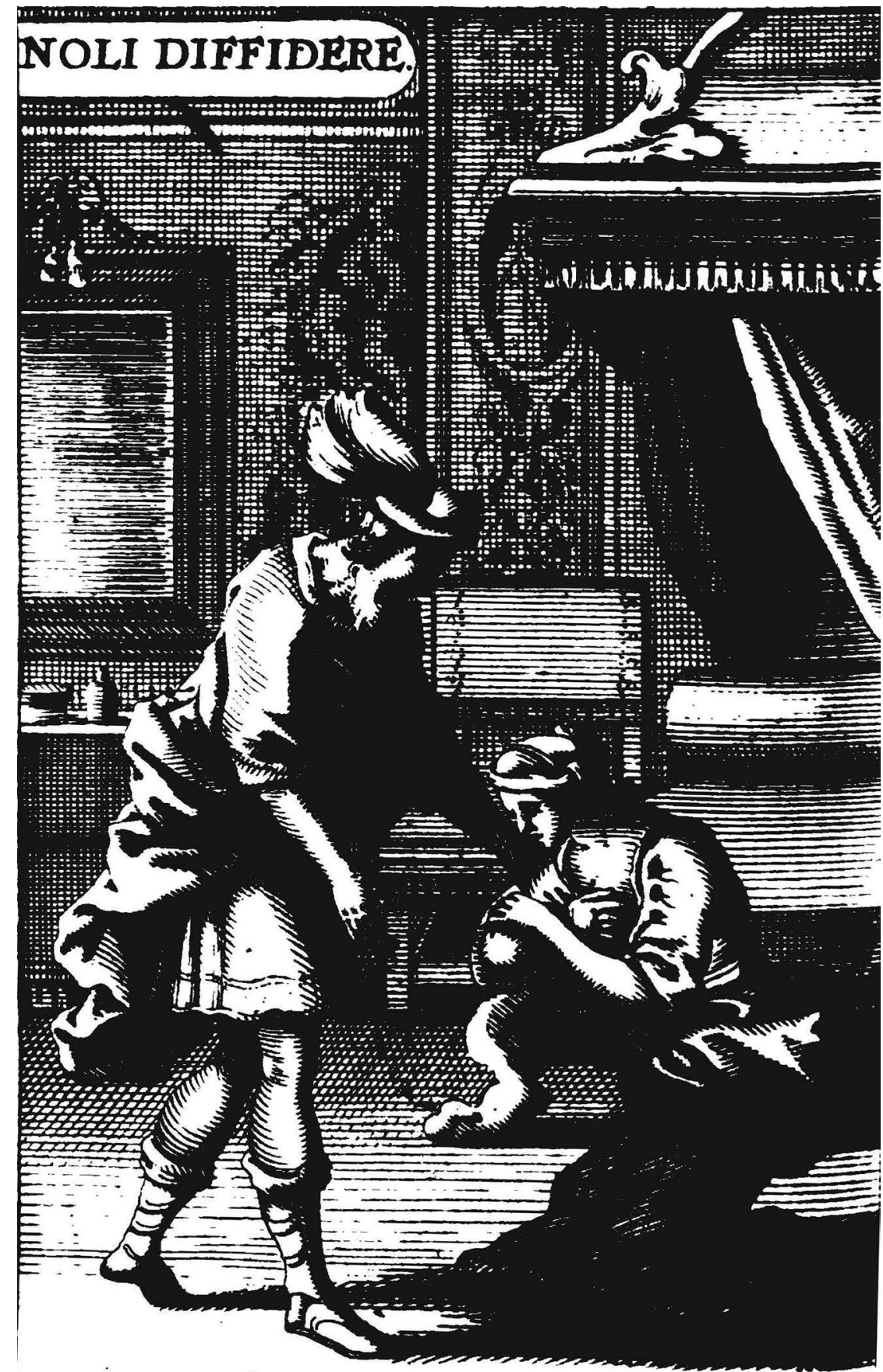

Figure 4. Ste Marie nièce de St Abraham est convertie par son oncle dans le lieu même où elle se prostituait. 


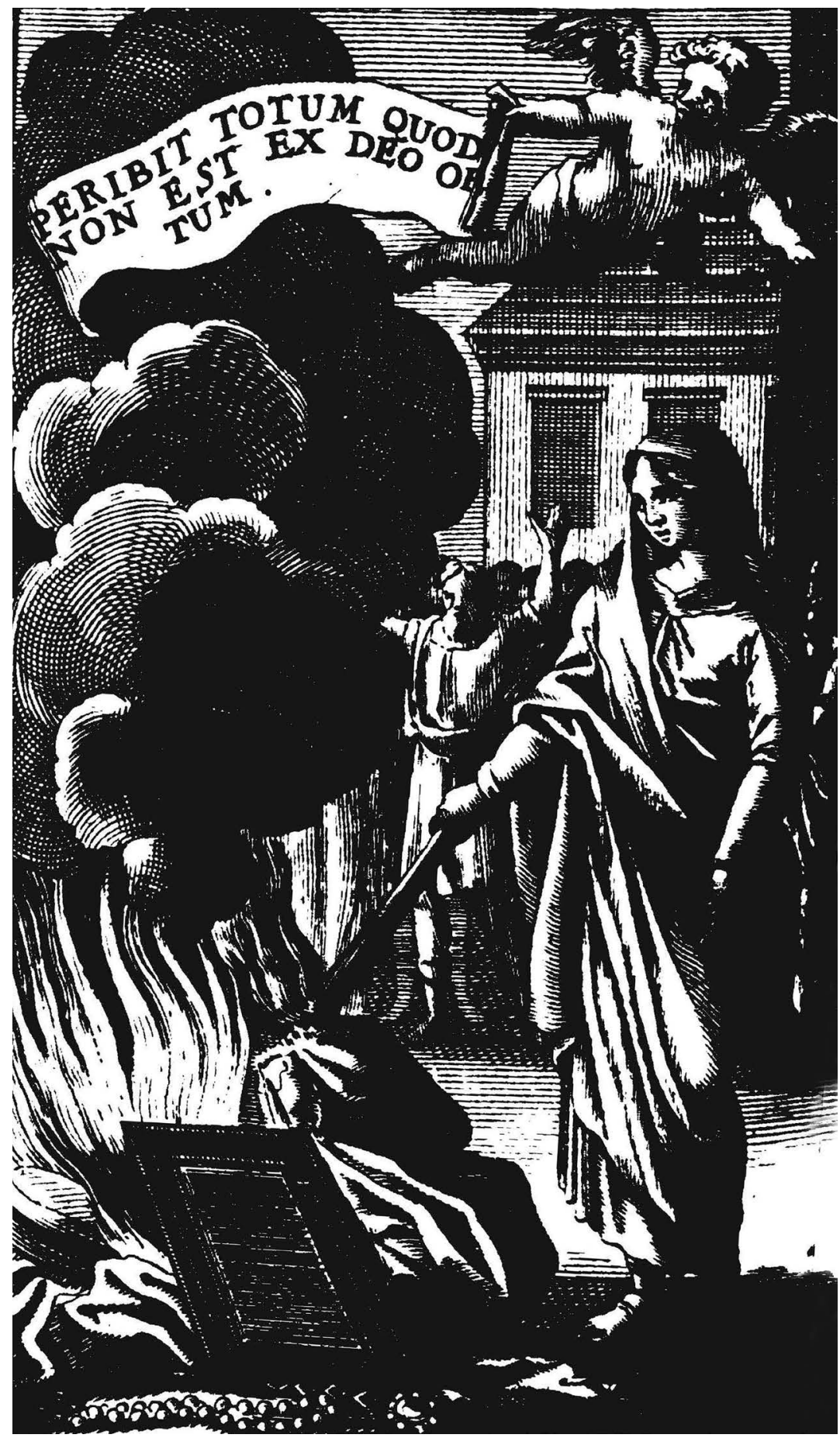

Figure 5. Ste Thaïs brûle en la place publique d'Alexandrie tous les meubles précieux qu'elle avait acquis par le péché. 


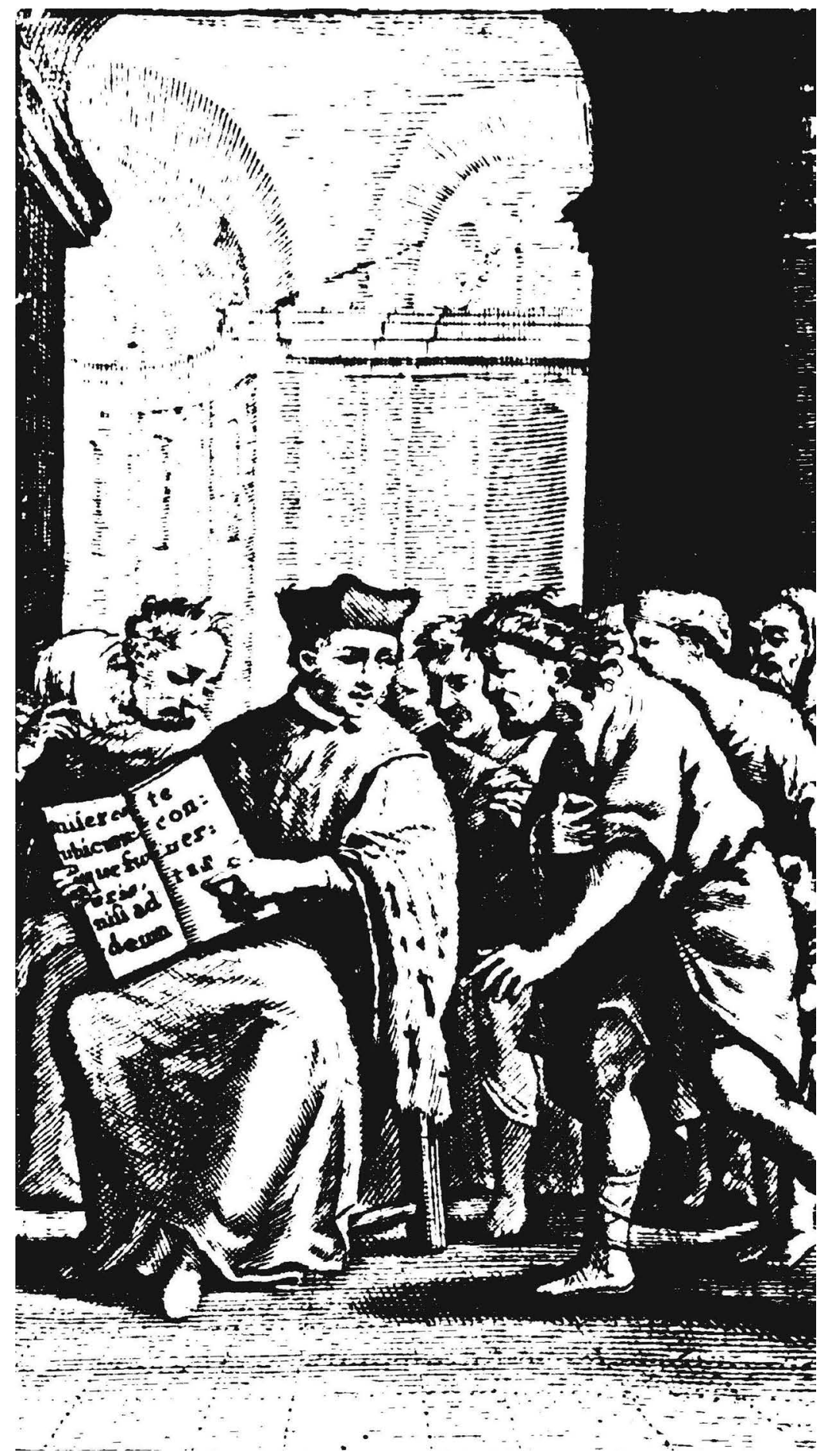

Figure 6. THOMAS A KEMPIS convertit plusieurs séculiers par la lecture de cette sentence. 
So Corneille, by his verse forms and by his emblems introduces, pace Voltaire, a great deal of both poetic and dramatic life to the referentially more austere original, a degree of expansion which is made more visible again in some editions ${ }^{41}$ by the provision of the Latin prose as a marginal framework text. As André Stegmann remarks: 'Bien que Corneille s'efforce de suivre au plus près son modèle latin, et souvent y réussisse étonnamment, malgré lui ce qu'il ajoute au texte va dans le sens de son expression dramatique' ('Although Corneille strives to follow closely his Latin model, and indeed often succeeds remarkably well in doing so, it is as if everything he adds to the text, despite himself, goes in the direction of its dramatic expression'). ${ }^{42}$

\section{PIERRE CORNEILLE: THEODORE, VIERGE ET MARTYRE, TRAGEDIE CHRETIENNE (1645-6) ${ }^{43}$}

If certain of these more lurid illustrations evoke the dramatic potential of such witness, they equally give rise to the question as to how such ordeals could be portrayed theatrically by dramatists such as Corneille with the decorum which the French stage increasingly required. How, in other words, are rape, torture or prostitution, all of which feature frequently in the lives of the saints which are depicted, compatible with the evolving imperative of bienséance? ${ }^{44}$

This kind of difficulty is strikingly confronted in one of Corneille's own martyr tragedies, Théodore vierge et martyre, dating from 1645-6 (so in fact shortly before his Imitation of Christ) and generically designated as a 'tragédie chrétienne' ${ }^{45}$ In this play, the Christian virgin Théodore is persecuted by pagan authorities, most notably by the wife of Valens, governor of Antioch, the dramatically powerful Marcelle, ${ }^{46}$ whose stepson, Placide, is in love with the eponym, and loved in turn by her moribund and non-appearing daughter, Flavie. ${ }^{47}$

\footnotetext{
${ }^{41}$ See for example the 1656 quarto edition, where the Latin text is reproduced in the margin.

${ }^{42}$ Corneille (1963a), 906.

${ }^{43}$ Théodore, vierge et martyre, tragédie chrétienne in Corneille (1984e), II, 267-343.

${ }^{44}$ Couton remarks that the 'comédie de dévotion' remains an unsolved problem in the period, and 'traduit l'inquiétude profonde d'une civilisation, qui ne réussit pas toujours bien à concilier christianisme et humanisme païen' ('translates the deep disquiet of a civilisation which does not always manage to reconcile Christianity and pagan humanism') (Corneille (1984e), II, 1316).

${ }^{45}$ The source text is thought by Stegmann to have been by Faustini (1618), providing the basis for the character of Marcelle (Corneille (1963b), 391).

${ }^{46}$ For Couton, she is 'le seul personnage sadique du théâtre cornélien' ('the only sadistic character in Corneille's theatre') (Corneille (1984e), II, 1330). Neither Marcelle nor Valens figures in the hagiographic sources.

${ }^{47}$ The play was a flop in Paris, although apparently more successful in the provinces. See Corneille (1984e), II, 1313 and n. 2.
} 


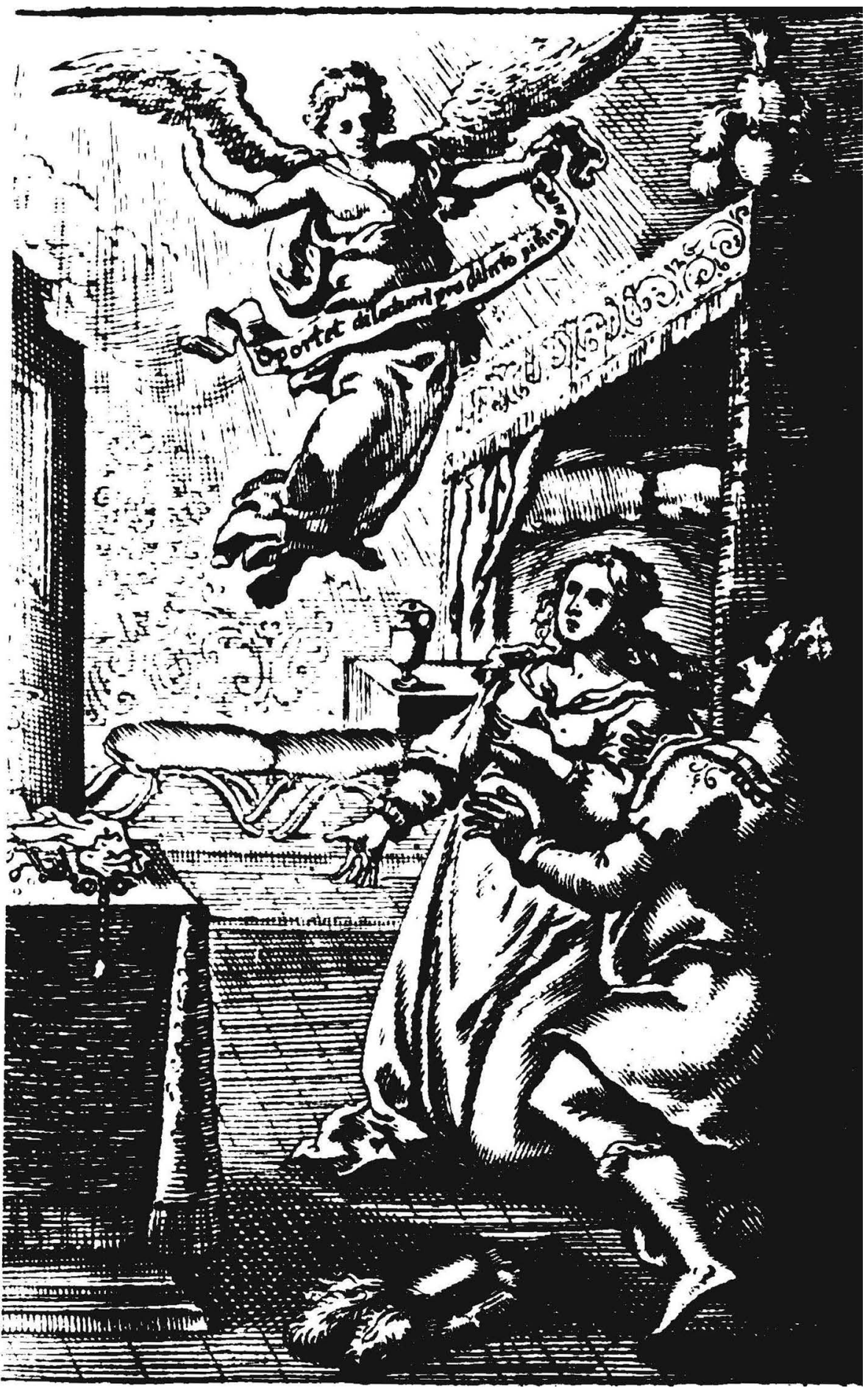

Figure 7. Ste Cécile et son mari s'entrequittent pour se donner à Dieu le soir de leur mariage. 


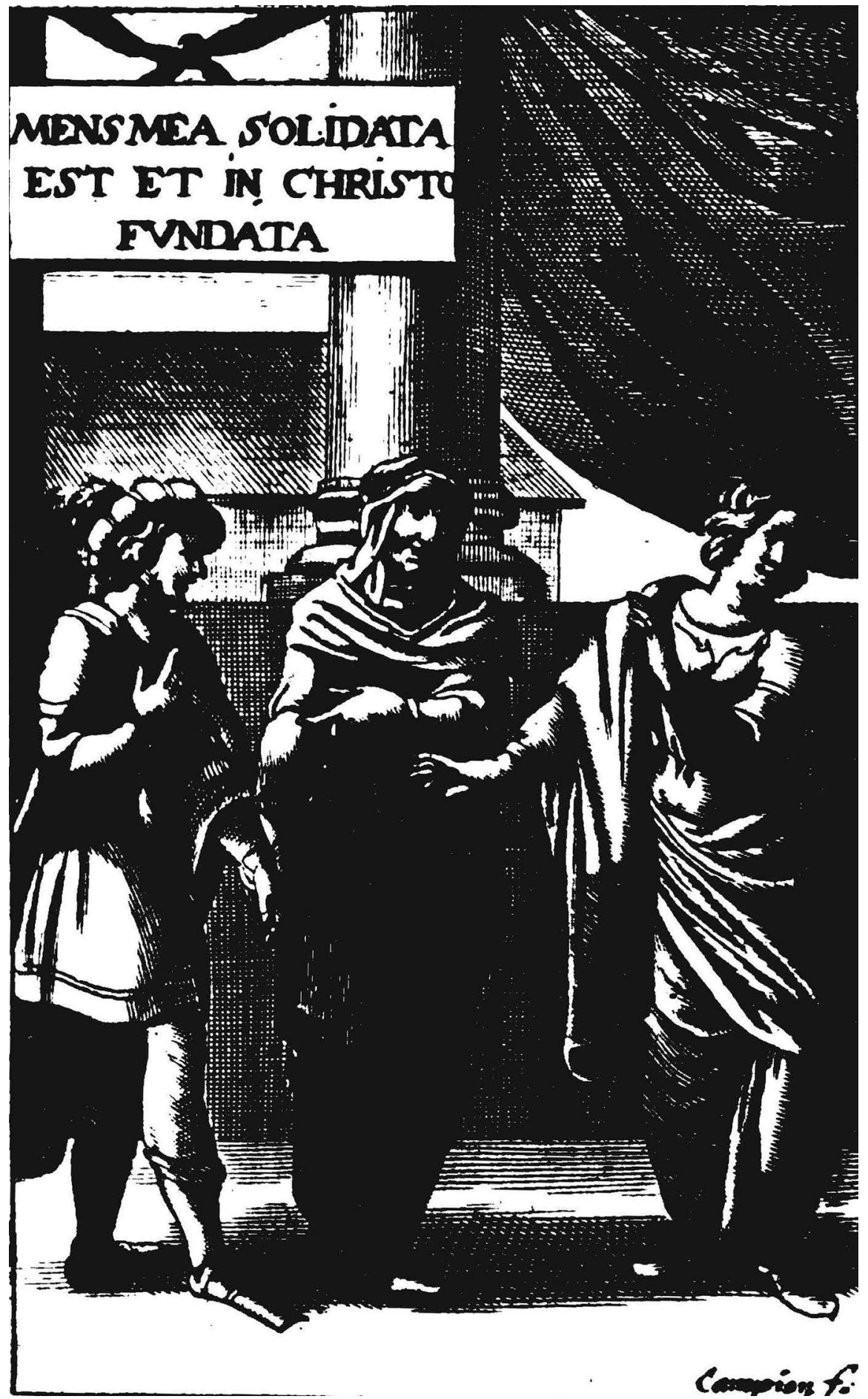

Figure 8. Ste Lucie refuse le mari que sa mère lui présente pour se donner à Jésus-Christ. 
Now the status of virginity as a Christian ideal is frequently promoted in the period, ${ }^{48}$ and also figures among Corneille's gravures in such closely comparable examples as St Cecilia and St Lucy (see Figures $7 \& 8$ ). Writing of virginity in his Panégyrique de St Joseph, Bossuet comments: 'C'est une imitation de la vie des anges [ . . .]; elle élève tellement la chair qu'elle l'égale en quelque façon [. . .] à la pureté des esprits' ('it is an imitation of the life of the angels [. . ]; it raises up the flesh to such a degree that it makes it equal in some way [. . .] to the purity of the spirits') ${ }^{49}$ The virgin is scripturally the mother of Christ, of course, but also devotionally the bride of Christ. As Théodore says in a memorably resonant line, she will offer 'A l'époux sans macule une épouse impollue' ('To the immaculate spouse an undefiled bride'), ${ }^{50}$ a covenant which she then develops in her profession of faith in the third act of the play: 'Chrétienne, et sous les lois d'un plus puissant époux $\|[$. . .] [C'est] enfin à lui que mes vœux ont donnée [sic] | Cette virginité que l'on a condamnée' ('As a Christian, and obedient to the laws of a more powerful spouse, $\|[$. . .] It is to him that my vows have accorded | This virginity which has been condemned'). ${ }^{51}$ And, if it is threatened by the advances of even such a noble suitor as the pagan Placide, she will prefer to die: 'Plutôt que dans son lit', she asserts, 'j'entrerais au tombeau' ('I would go into the tomb more readily than I would go into his bed') ${ }^{52}$ (although the introduction of suicide as a means of achieving this aim introduces a further ethical dilemma, only questionably resolved by the introduction of divine authorisation: 'Ma loi me le défend', she accepts, 'mais mon Dieu me l'inspire' ('My law forbids it, but my God inspires it')). ${ }^{53}$ The thematics of virginity and martyrdom are thus introduced at an early stage in the play, even if neither, for the time being, is accorded any dramatic or tragic potential-virginity because of its passivity, and death because it will be embraced by the Christian martyr as a triumphant path to glory. ${ }^{54}$

${ }^{48}$ Couton notes that there was a sub-set of virgin stories in the martyrologies popular in the period (especially the Fleur des Vies des Saints of the Jesuit Pedro de Ribadeneyra, in the translation of 1620 by Robert Gautier), notably those devoted to St Agnes and St Theodora, both of whom preferred death to defilement. He suggests that Corneille's Theodora play borrows certain features more correctly attributed to the Agnes narrative (Corneille (1984e), II, 1323), to which there is indeed a direct reference in Théodore, $\mathrm{V}, 5,1639-42$. There is also a substantial corpus of such tragedies in the earlier years of the century, often taken from Italian models.

${ }^{49}$ Panégyrique de Saint Joseph, in Bossuet (1961), 332. Allying virginity to martyrdom, St François de Sales evokes, in a pair of contrastive colour images, 'des martyrs plus vermeils que la rose, des vierges plus blanches que le lis' ('martyrs who are more scarlet than roses [and] virgins who are whiter than lilies') (Traité de l'amour de Dieu, in François de Sales (1969), 319-972, 729).

50 Théodore, III, 1, 780.

${ }^{51}$ Théodore, III, 3, 869; 875-6.

${ }^{52}$ Théodore, II, 4, 518.

${ }^{53}$ Théodore, III, 3, 911.

${ }^{54}$ And indeed the pagan suicides of the vindictive Marcelle and the nobly altruistic Placide which follow 
The true dilemma of the play therefore only begins to be felt as the second act ends. In reply to Marcelle's provocative: 'Ainsi donc vous laissez Théodore impunie?' ('So you are leaving Théodore unpunished?'), her husband Valens retorts: 'Non, je la veux punir, mais par l'ignominie' ('No, I wish to punish her, but by ignominy'), an allusion received tellingly enough by Marcelle with a degree of incomprehension that is no doubt only equalled by that of the audience..$^{55}$ And indeed, even at this stage, only the most veiled of prolepses is afforded of the play's central dilemma. ${ }^{56}$ What soon becomes clear, however, is that Théodore will be forced to confront, not virginity and martyrdom, but idolatry and defilement. ${ }^{57} \mathrm{Up}$ to this point, the play is a web of euphemism, irony and ambiguity; but now the full horror of Théodore's punishment can, however vicariously, be exploited. The dramatic and aesthetic dilemmas thereby come together, and are resolved or aggravated, according to your point of view, in the fact that the crime-fitting punishment planned for Théodore by her pagan oppressors is that she should be forced to endure prostitution by the military. She will thus be imprisoned and subjected to rape by the Roman soldiers; and this defilement will in turn be dedicated to the pagan gods, in a reversal of the Christian (and indeed Christic) consecration of her virginity.

But, in the play's most extraordinary peripeteia, it is Placide's Christian rival, Didyme, who devises the ploy to save Théodore by going himself into her prison with the declared intention of seducing her, but with the real strategy of allowing her to escape in his clothes. ${ }^{58}$ This substitution is both justified morally in terms of the greater good of martyrdom being preferable to the ignominy of rape, and rendered dramatically necessary in order to maintain bienséance. The transvestite escape itself is inevitably if masterfully portrayed by a heavily ambiguous récit: 'Ses cheveux sur son front s'efforçaient de cacher | La rougeur que son crime y semblait attacher, | Et le remords de sorte abattait son courage, | Que même il n'osait plus nous montrer son visage. | L'œil bas, le pied timide et le corps chancelant, | Tel qu'un coupable enfin qui s'échappe en tremblant' ('With his hair on his forehead he tried to conceal| The blushes which

the Christian martyrdoms of Théodore and Didyme at the dénouement could well be seen, in a more conventional understanding of the genre, as equally consistent with the requirements of tragedy.

55 'Je ne vous entends point' ('I do not understand you') (Théodore, II, 6, 651-5).

${ }^{56}$ As Couton notes, 'la scène où pour la première fois elle est avertie qu'elle sera prostituée n'a pas été écrite' ('the scene in which for the first time she is warned that she will be prostituted was never written') (Corneille (1984e), II, 1324).

57 'L'idolâtrie et l'impudicité' (Théodore, III, 1, 770).

${ }^{58}$ Didyme is, however, by definition unable to aspire to Théodore. As Couton puts it, 'il a un rival irrésistible, le Christ' ('he has an irresistible rival, Christ') (Corneille (1984e), II, 1325). Couton also notes: '[Il] aime Théodore en Dieu, comme l'Imitation de Jésus-Christ recommande qu'on aime les femmes' (' $[\mathrm{He}]$ loves Théodore in God, as the Imitation of Christ recommends that women should be loved') (Corneille (1984e), II, 1325), and cites in evidence Corneille's Imitation, I, 8. 
his crime seemed to attach to it [purportedly the act of seducing Théodore], | And remorse so defeated his steadfastness | That he did not even dare to show us his face, | So that, with his eyes averted, his foot stumbling and his body shaking | He left like a guilty man who fearfully escapes'). ${ }^{59}$ But, although Corneille himself criticises this development, it does at least finally allow for the more dramatic subject of martyrdom to take over from the more passive one of virginity in the later stages of the play. ${ }^{60} \mathrm{As}$ a result, the dénouement can now be couched in terms which contain more tragic potential (at least in Cornelian terms), ${ }^{61}$ and indeed which become more and more extreme in their enunciation, as the heroine competes with her Christian lover Didyme for, as they would have it, the privilege of a violent death.

But if Théodore as a martyr thereby achieves her ultimate triumph, Théodore as a play seemed to be doomed to failure on two counts: either, extrinsically, by the increasingly rigorist Church of the period, since even the threat of prostitution was considered too unseemly to contemplate on the stage; or, intrinsically, and by the judgement of posterity, because the subject of virginity was considered insufficiently dramatic as a basis for tragedy. ${ }^{62}$ Indeed Corneille acknowledges in 1660 in the self-critical Examen de Théodore that he had found himself caught between these two dilemmas. As he seeks to account for the relative unpopularity of his play, ${ }^{63}$ he first of all accords some attention to the reported scene of unrealised prostitution, within the obvious context of bienséance or its lack. His defence, in which he claims, not without irony, to have shown more decorum than his patristic models, is perfectly tenable: '[Pour] en exténuer l'horreur' he writes, '[j'ai] employé tout ce que l'art et l'expérience m'ont pu fournir de lumières. [. . .] Dans cette disgrâce j'ai de quoi congratuler à la pureté de notre scène, de voir qu'une histoire qui fait le plus bel ornement du second livre des Vierges de

\footnotetext{
59 Théodore, IV, 3, 1277-82.
}

${ }^{60}$ Couton notes that the dénouement is entirely the invention of Corneille (Corneille (1984e), II, 1326). He also asks whether 'Corneille [a] voulu [. . .] faire de sa vierge une allégorie du théâtre chrétien' ('Corneille wanted [. . . to make of his virgin an allegory for Christian theatre') (Corneille (1984e), II, 1321).

${ }^{61}$ Corneille makes the point clearly in his Examen de Nicomède that he seeks to elicit, rather than terror and pity, the response of 'admiration'-that is astonishment, amazement - in his audience (Corneille (1984e), II, 634). This outcome is also in accordance with the Cornelian desideratum of 'unité de péril' as articulated in the Discours des trois unités (Corneille (1984b), III, 174-90, 174).

${ }^{62}$ As opposed to, say, iconoclasm initiated (such as in Corneille's earlier martyr tragedy, Polyeucte martyr (1643)), or torture endured, even if the second of these does in fact constitute the play's outcome. Indeed some contemporary critics regretted that a love intrigue had been deemed necessary at all (see Couton in Corneille (1984e), II, 1313).

${ }^{63}$ Even if, as Marty-Leveaux comments, 'la pièce ajouta un intérêt tout profane à la pieuse curiosité qu'excita la translation des reliques de la sainte dans le monastère des Ursulines à Caen' ('the play added an altogether profane interest to the pious curiosity which was aroused by the translation of the relics of the Saint to the Ursuline monastery at Caen') (Corneille (1862-8b), Vol. V, 6). 
saint Ambroise, ${ }^{64}$ se trouve trop licencieuse pour y être supportée' ('To extenuate the scandal of it, I have used all the enlightenment that art and experience can have afforded me. [. . .] I nonetheless find in the opprobrium which I have endured a reason to congratulate the purity of our theatre, and to note that a story which adorns the second book of St Ambrose's Virgins is considered too licentious to be tolerated [on the French stage]' ${ }^{65}$ But he also acknowledges the problem of the hagiographic subject-matter, conceding that 'une vierge et martyre sur le théâtre, n'est autre chose qu'un terme qui n'a ni jambes ni bras, et par conséquent point d'action' ('a virgin martyr on the stage is nothing more than a sort of Terminus, who has neither arms nor legs, and as a result no action'). ${ }^{66}$

Others were equally critical, thus the Abbé D'Aubignac in his 1657 Pratique du théatre pre-empts the dramatist's self-appraisal by his comment that, however elegantly it was expressed, 'parce que tout le théâtre tourne sur la prostitution de Théodore, le sujet n'en a pu plaire' ('the subject was not able to please, because the whole play turns on the prostitution of Théodore'). Although he then concedes in a grudging double negative: 'Ce n'est pas que les choses ne soient expliquées par des manières de parler fort modestes, et des adresses fort délicates' ('It is not that these things were not explained in very modest idioms and very delicate speeches'), before insisting that 'il faut avoir tant de fois dans l'imagination cette fâcheuse aventure, et surtout dans les récits du quatrième acte, qu'enfin les idées n'y peuvent être sans dégoût' ('you have so often to keep this tiresome adventure in your imagination, above all in the récits of the fourth act, that, as a result, the ideas [conveyed by it] cannot fail to offend') ${ }^{67}$ Voltaire too, a century later, was predictably more scathing, although within the same balance of criticisms for the most part. On the one hand, he insists, the subject is replete with what he calls 'les indécences les plus révoltantes' ('the most revolting of indecencies'), involving the attempt to accompany 'une turpitude si odieuse et si ridicule de tous les mauvais raisonnements qu'une telle impertinence peut suggérer' ('such an odious and ridiculous depravity by all the worst justifications to which such a lack of decorum can give rise'); while on the other he considers that 'une fille de qualité qui veut mourir vierge est fort bonne pour le couvent et fort mauvaise pour le théâtre' ('a well-born young woman who wishes to die a virgin is very good for a convent and very bad for the stage'), before throwing in for good measure his opinion that 'cette fin est funeste, mais elle n'est pas touchante' ('the dénouement is sombre without being affecting'). ${ }^{68}$ The theatrical potential of the imitators of Christ, at least with respect to the aesthetics of nascent classicism, was not a tidy business.

${ }^{64}$ That is the De Virginibus of the 4th-century Latin Doctor of the Church.

${ }^{65}$ Examen de Théodore in Corneille (1984e), II, 271.

${ }^{66}$ Corneille (1984e), II, 272.

${ }^{67}$ In D’Aubignac (2001), p. 110.

${ }^{68}$ Commentaires sur Corneille II, in Voltaire (1974-5), Vol. 54, 457-75: 458, 457, 468, 474. 


\section{JEAN-JOSEPH SURIN: TRIOMPHE DE L'AMOUR DIVIN SUR LES PUISSANCES DE L'ENFER (1653) AND SCIENCE EXPERIMENTALE DES CHOSES DE L'AUTRE VIE (1660)}

Accounts of Christ's imitators in the period also take non-dramatic, or at least non-theatrical forms, most obviously in the lives of saints, but also in the spiritual autobiographies of contemporary holy men and women, even if these are situated at a range of distances from both sanctity and sanity. One of the most disconcerting of such documents takes the form of a composite project undertaken by Jean-Joseph Surin, a Jesuit priest from Poitiers sent to the Ursuline convent at Loudun in order to restore order to a community of nuns that had allegedly fallen victim to diabolic possessions (a narrative which forms the basis both of Aldous Huxley's sceptical analysis in The Devils of Loudun and of Ken Russell's sensational film The Devils ${ }^{69}$ ).

Surin's writings consist of a purportedly descriptive and objective account of the events surrounding the nun at the centre of the controversy, Mère Jeanne des Anges, dramatically entitled Triomphe de l'amour divin sur les puissances de l'enfer [Triumph of divine love over the powers of hell], alongside the autobiography of Surin himself, whose title is equally if not more arresting: Science expérimentale des choses de l'autre vie [Empirical knowledge of things from the other life].$^{70}$ Resonances of Thomas à Kempis occur in the autobiography when he speaks, for example, of '[le] combat qu'il faut livrer contre les ennemis de notre salut, et [. . .] la charge qu'il faut porter dans le service d'un Maître qui mérite tout, et qui ne nous doit rien, et qui, quand il accroît nos misères, honore ses miséricordes' ('[the] combat that we must pursue against the enemies of our salvation and [. . . the burden which we must carry in the service of a Master who deserves everything, and who owes us nothing, and who, when he increases our sorrows, honours his mercies') ${ }^{71}$ but the link to my title is made more explicit again in the function of the exorcist as a surrogate Christ: '[Surin]', he writes of himself in the third person, 'se proposa que son grand bonheur serait d'imiter JésusChrist, qui, pour tirer les âmes de la captivité de Satan, avait souffert la mort après s'être chargé de leurs infirmités' ('[Surin] considered that his greatest happiness would be to imitate Christ who, in order to free souls from the captivity of Satan, had suf-

\footnotetext{
${ }^{69}$ As well as a more probing account in the 20th century by the fellow Jesuit Michel de Certeau, contained in Surin (1990).

${ }^{70}$ In Surin (1990).

${ }^{71}$ Science, 191. Or when he comments, in reporting a verbal revelation attributed to the Holy Spirit, that 'Dieu donne ses grâces à l'âme pour qu'elle s'en serve' ('God gives his graces to the soul so that it may use them'), but that, since 'ses conduites sont différentes et très secrètes, il tirera sa gloire des humiliations de son serviteur' ('his ways are different and very secret, he will draw his glory from the humiliations of his servant') (Science, 322). In addition, Surin's own Fondements de la vie spirituelle, published posthumously, are explicitly drawn from the text of the Imitation of Christ.
} 
fered death after taking their infirmities onto himself').${ }^{72} \mathrm{He}$ is thus obliged in his role as exorcist to follow 'l'ordre que [Dieu] tient en toutes ses œuvres, qui est de permettre que ceux qui doivent faire quelque chose pour lui, soient humiliés, criblés et anéantis comme son Fils qui succomba quant à l'extérieur sous les efforts du Prince des ténèbres, avant qu'il le chassât du monde' ('the order that [God] obeys in all his works, which is to allow those who are destined to work on his behalf to be humiliated, crippled and annihilated like his Son, who succumbed, as far as appearances were concerned, to the efforts of the Prince of darkness, before banishing him from the world').${ }^{73}$ The ministry of exorcism is furthermore identified as emanating from the power of the Church, so that 'quand l'exorciste fait son devoir, s'y comportant avec un esprit désintéressé et prudent, Notre-Seigneur les [=démons] oblige alors à faire ce que l'Église désire par ses ministres' ('when the exorcist does his duty, going about it in a prudent and disinterested state of mind, Our Lord obliges [the devils] to do what the Church requires by its ministers'), ${ }^{74}$ including, perversely (at least from a diabolic point of view) their enunciation of Christian truths. Most intriguingly of all, therefore, Christian symbols occur at the very moment of diabolic evacuation. Thus Surin, with the Blessed Sacrament in his hands, defeats the devil, Leviathan, who 'se prosterna ensuite aux pieds du Père, s'étendit sur le marchepied de l'autel, les bras étendus en croix sur la terre, et sortit aussitôt, laissant la Mère libre qui [. . .] parut avec une croix sanglante sur le front, gravée et imprimée sur sa peau, selon la promesse du demon' ('prostrated himself thereafter at the feet of the Father, stretched himself out on the steps of the altar, with his arms extended in the shape of a cross on the ground, and surrendered immediately, leaving the Mother free, who [. . .] appeared with a bleeding cross on her forehead, engraved and imprinted on her skin, just as the devil had promised'). ${ }^{75}$

In a way, therefore, such episodes contain the story not of one but of three divergent imitations of Christ: that of the exorcist, first of all, in assuming Christ's burden willingly; that of the liberated sister, in bearing the marks of her redemption (and, in the case of Jeanne des Anges, of claiming miraculous powers as a result); but also that of the demonic forces, whose protean manifestations are initially deployed in order to deceive the victims of their possession, yet whose capitulation transforms their acts of impersonation into acts of submission. The Triomphe de l'amour divin indeed seems at times to present a sort of diabolic theology, whereby the demonic forces explain their aspirations and frustrations and, significantly enough, specify that they lose their power by three of the salient practices commended in the Imitation of Christ: 'Nous

\footnotetext{
${ }^{72}$ Triomphe, 27.

${ }^{73}$ Triomphe, 36.

${ }^{74}$ Science, 144.

${ }^{75}$ Triomphe, 99.
} 
perdons tous nos droits', the demons admit, 'par ces trois choses, l'oraison, l'humilité et la pénitence' ('We lose all our rights by these three things: by mental prayer, by humility and by penitence'). ${ }^{76}$

But if Surin's subject-matter is of itself disquieting, his mode of narration is equally perplexing; and it is in the autobiography, the Science expérimentale, that the reader is most disconcerted. Because, uniquely within its sub-genre, Surin's account shifts constantly from the first to the third person and back again, not only from paragraph to paragraph, but even within grammatical units; and all sorts of hypotheses are attractive as to why this should occur, even if none is consistently applicable. It is tempting, for example, to infer that the shift occurs when the story of the possession of the nun turns to that of the possession of the exorcist, as it frequently does; or that the writer, now freed from his demonic ordeal, can only describe it retrospectively as if it were happening to another person. Most often indeed it seems to reflect the distinction between the narrating present and the narrated past, thus: '[Les] impressions du désespoir se formaient en lui. Très souvent au milieu de ces peines infernales, il [lui] venait des instincts de s'unir à Jésus-Christ, avec des unions avec lui fort délicieuses, et dont le souvenir me touche fort maintenant, mais qui se perdaient et s'oubliaient du tout quand le désespoir retournait' ('Impressions of despair rose up in him. Often in the midst of these infernal ordeals, the impulse would occur [to him] to unite himself to Christ, by some kind of delicious union with him, the memory of which touches me powerfully now, but which was altogether lost and forgotten as soon as the despair returned'). ${ }^{77}$ But neither really copes with the progressively more rapid transitions in the narrative, any more than do the writer's periodic commentaries on the phenomenon, such as in a disconcerting moment of self-awareness: 'Je parle ici tantôt à la première personne, tantôt en la troisième, et je suis, je ne sais comment, détourné de ma route, sans savoir aussi comment j'écris avec liberté, comme si je n'étais que pour moi-même' ('I am speaking here sometimes in the first person, sometimes in the third, and I have, I don't know how, swerved from my path. Nor do I know how I write so freely, as if I had only myself to answer for')..$^{78}$

What such chaotic ramblings progressively suggest, as not only their syntax but even their meaning becomes unclear, is the mimetic transmission of a state not of self-abasement but of self-alienation. Yet in other respects this only takes the Christic analogy one stage further, since the manifestation of folly is itself presented as Christlike, with St Ignatius cited in support: 'Notre-Seigneur, par sa providence, l'avait destiné à cela', he now writes of himself in the third person, 'sur la méditation d'une de

\footnotetext{
${ }^{76}$ Triomphe, 73.

77 Science, 202. My emphases. The translations do not aim to convey the stylistic eccentricities of the original.

${ }^{78}$ Science, 204.
} 
nos règles, par laquelle saint Ignace veut que nous soyons disposés à être tenus pour fols [. . . ] car il a été comblé de ce bien par lequel il a été conforme à Jésus-Christ, qui chez Hérode a été tenu comme fol et traité comme tel' ('Our Lord, by his Providence, had destined him for this, on the meditation of one of our rules, by which St Ignatius wants us to be prepared to be taken as mad [. . . for he was filled with this gift according to which he was made in conformity with Christ, who in Herod's court was held to be mad and treated as such'). ${ }^{79}$

Endorsing this mimetic dimension is the tendency to use the Church's year as a structuring device, and so to calque the human ordeal chronologically on the liturgical model, thus, for example, in a sequence which begins: 'Quelque temps après, en suivant l'ordre de la vie de Jésus-Christ, ils vinrent jusqu'aux mystères de la Passion' ('Some time later, following the order of the life of Christ, they reached the mysteries of the Passion').$^{80}$ This attains its culmination as the Agony in the Garden is transposed onto Surin's soul, ${ }^{81}$ and climaxes, on the Feast of the Invention of the True Cross, in his experience of the Crucifixion:

Je me sentis saisi de quelque véhémence qui portait l'âme à ressentir la croix de JésusChrist, et comme ces frémissements, ainsi que de fièvre, eussent fait le commencement, je sentis quelque présence qui me fit étendre et roidir les bras d'une telle manière, que je fus ôté de dessus mon siège, et puis descendu peu à peu jusqu'à terre, puis étant sur la terre, je fus avec la même roideur qui bandait les muscles et les nerfs, mis comme en croix, et dans l'esprit me fut représenté le délaissement de Jésus-Christ en la croix, et ce supplice mis en l'esprit, comme chose non pas seulement représentée, mais imprimée.

(I felt seized with some vehemence which carried the soul to feel the cross of Christ, and when this trembling, as if in a fever, had started, I felt some presence which made me stretch out my arms, and stiffen them, in such a way that I was lifted from my seat and then little by little lowered to the ground; then, when I was on the ground, I was, with the same rigidity in my muscles and nerves, put as if on a cross, and in my spirit there was represented the abandonment of Christ on the cross, and this torment put into my mind, as something that was not just represented, but imprinted there). ${ }^{82}$

The possessed sisters have a similar cast of mind as well, such as when Jeanne des Anges 'pria le Père de lui permettre qu'on l'attachât à un pilier qui était dans la chambre, pour y être disciplinée par ses sœurs, ainsi que Notre-Seigneur à la colonne'

\footnotetext{
${ }^{79}$ Science, 179-80. As well as the obvious Pauline resonance (1 Corinthians 1:25), the tonality here is very close to that of the Spiritual Exercises of St Ignatius (2004), 98, 167.

${ }^{80}$ Triomphe, 63.

${ }^{81}$ Science, 259-60.

${ }^{82}$ Science, 262, cf. Ibid., 271-2.
} 
('asked the Father [Surin] to allow her to be attached to a pillar which was in the room, so as to be scourged by her sisters, as Our Lord was at the column'). ${ }^{83}$

But this kind of apparent proximity of experience brings two underlying definitions into question. The first is the problematic role of the imagination, to which faculty Surin frequently appeals in his search to imitate Christ. At its simplest level, he on one occasion fends off the devil, now in the form of a serpent, by calling to mind a picture of the Virgin holding the Christ-child 'comme il l'avait vu en des tableaux' ('as he had seen it in pictures'), and the devil then admits that it was impossible for him to operate in the imagination of the possessed man, since it was already occupied by the picture of the Virgin. ${ }^{84}$ But the phenomenon is then developed in a later chapter of the Science expérimentale, where Surin receives the assurance from God that Christ's five wounds will be engraved on his soul. He goes on to explain that, ever since, 'je n'ai jamais manqué d'avoir une facilité de me les représenter à mon imagination, comme si je les avais effectivement' ('I have never lacked the facility to represent them to my imagination, as if I really had them'), ${ }^{85}$ and that this imagination is a source of perpetual consolation to the soul of the priest. ${ }^{86}$ But it is in this context too that Surin's status as a Jesuit once again brings to mind the Spiritual exercises of St Ignatius Loyola, whose enactment is explicitly evoked in the Triomphe de l'amour in terms of an antidote to diabolic possession. ${ }^{87}$ The essential feature of the experience lies in recognising, as Barthes points out in his essay, that the imagination for Ignatius is distinct from the imaginaire: ${ }^{88}$ there is no attempt to conjure up the unknown or unreal in the composition de lieu, but rather to evoke as fully and precisely as possible that which is attested scripturally or historically, in order, in other words, to achieve a more intimate union with the divine.

The second question is to wonder how such accounts correspond to what we have, in relatively recent critical language, come to identify as an autobiography? They certainly fulfil Philippe Lejeune's minimal criterion of being a retrospective prose narrative in which the emphasis is placed on the evolution of the personality; ${ }^{89}$ but one in

\footnotetext{
${ }^{83}$ Triomphe, 97.

${ }^{84}$ Triomphe, 37.

${ }^{85}$ Science, 289.

${ }^{86}$ Science, 292.
}

${ }^{87}$ This is the title of the fifth chapter of the Triomphe: 'De la voie qui fut tenue en la conduite de l'oraison de la Mère prieure, de la grande résistance que les diables y apportèrent et comme elle fut ordonnée selon la forme des Exercices spirituels de saint Ignace, avec la grande bénédiction que Dieu donna à cette voie' ('Of the way that was followed in the practice of mental prayer by the Mother Prioress, of the great resistance which the Devils brought to it, and of how it was ordered according to the form of the Spiritual Exercises of St Ignatius, together with the great blessing that God accorded to this way') (Triomphe, 55). ${ }^{88}$ Barthes (1971), 54.

89 'Nous appelons autobiographie le récit rétrospectif en prose que quelqu'un fait de sa propre existence, quand il met l'accent principal sur sa vie individuelle, en particulier sur l'histoire de sa personnalité' ('We 
which the topoi of sincerity and veracity are subtly expanded. The first addition is that of both scriptural and more broadly spiritual authority, initially expressed by Surin with a Johannine resonance: 'Ainsi je suis plus croyable que cent autres qui sont venues à différentes heures' he writes, 'disant qu'ils n'ont rien vu, et qui se mettent au rang de ceux qui disent qu'ils ne croient que ce qu'ils voient [. . .]. [Le] mérite de la foi est de croire à ceux qui nous disent, comme les apôtres: Nous avons vu le Verbe de vie, nous lui avons parlé' ('I am more believable than hundreds of others who have come at different times, saying that they have seen nothing, and lining themselves up with those who say that they only believe what they can see [...]. [The] virtue of faith is to believe what others tell us, such as the Apostles: We have seen the Word of life, and we have spoken to him'). ${ }^{90} \mathrm{He}$ then affirms later in the Science expérimentale that '[Quasi] continuellement j'étais investi de pareilles choses auxquelles je ne doutais point qu'il n'y eût du surnaturel sans faiblesse naturelle de l'imagination' ('I was [almost] continually entrusted with similar things of which I had no doubt that there was a supernatural dimension without any natural weakness of the imagination'), ${ }^{91}$ and stresses that a particular spiritual temperament will be required fully to empathise with his experiences, so admitting that a vision he receives will appear 'ridicule ou indécent à ceux qui ne la regarderont pas dans les bontés de Notre-Seigneur' ('ridiculous or indecent to those who do not perceive it in the goodness of Our Lord') ${ }^{92}$

The second amplification is the topos of inexpressibility, both by virtue of the transcendent nature of the experiences recorded, and by the (ironically ubiquitous) perception of their uniqueness in similar documents of the period. Thus Surin writes of how 'tout ceci est écrit d'un style fort grossier et fort simple, et encore avec grand désordre [.. .] mais j'ai traité au chapitre précédent une chose bien plus grande que je ne la puis exprimer, et je ne saurais faire connaître comme cela est' ('all this is written in a very coarse and simple style, and with great disorder as well, [. . .] but what I wrote of in the last chapter [the experience of the grace of union with Christ] is something so great that I cannot express it, and would not be able to convey how it was'). The inexpressible knowledge is thus limited to showing 'combien Jésus-Christ se rend intime à l'homme, et que sa familiarité va jusqu'à un point qu'on ne saurait imaginer ni comprendre [. . .] qui ne trouve rien de pareil en la nature' ('how far Christ makes himself intimately known to man, and how his familiarity reaches a point that cannot

call auobiography the retrospective prose narrative which someone writes of his own existence, when he places the principal emphasis on his individual life, and in particular on the history of his personality') (Lejeune (1971), 14).

${ }^{90}$ Triomphe, 141. Cf. John 20:29.

${ }^{91}$ Science, 274-5.

${ }^{92}$ Science, 293. 
be imagined or understood [ . . ] because there is nothing comparable to it in nature'). ${ }^{93}$ But to both of these is added a third purpose to his writing, which is the aim to 'fortifier la croyance que nous avons de Dieu, de Jésus-Christ et de son Église' ('fortify the belief we have in God, in Christ, and in his Church').${ }^{94}$ And it is in this way perhaps that even this most eccentric of Christian autobiographies returns to its originator, to the Confessions of St Augustine in other words,${ }^{95}$ and that, in so doing, it reinforces the most important aspect of that sub-genre, not just as a narrative of life but as a profession of faith.

\section{JACQUES-BENIGNE BOSSUET: EXPOSITION DE LA DOCTRINE DE L'ÉGLISE CATHOLIQUE SUR LES MATIERES DE CONTROVERSE (1655) AND FRAGMENTS SUR L'EXPOSITION (1753)}

I want finally to consider one of the ways in which Christ was most literally imitated in the Church, and that is in the words of institution of the Eucharist: Hoc est enim corpus meum. This formula not only constitutes the devotional nexus of the whole of the fourth book of the Imitation of Christ (the features of whose addressee now unambiguously identify him as a priest), but is furthermore one that is substantially expanded in Corneille's paraphrase of the original. In the illustrated 1656 edition, for example, the titular engraving represents, without any further description, a crowd of people kneeling before the ciborium, placed on a cloud, surrounded by angels and accompanied by the simple phrase: 'Venite ad me omnes'; and, whereas the Preface in the Latin original is composed simply of those seminal quotations from Scripture which prefigure, record or interpret the words of institution, ${ }^{96}$ these are amplified by Corneille with a Christic injunction: 'Dites ce que je dis pour faire comme moi; | L'efficace de votre foi | Produira même effet par les paroles mêmes' ${ }^{\text {'7 }}$ ('Say as I say in order to do as I do; | The efficacy of your faith | Will produce the same effect by the words themselves'). And this is later again expanded by the priest's apostrophe to God: 'Ta parole jadis fit sitôt toutes choses, | Que rien n'en sépara le son d'avec l'effet; | Et ta vertu passant dans les secondes causes, | A peine l'homme parle, et ton vouloir

${ }^{93}$ Science, 331. Similar formulas are found, for example, in the autobiographies of St Marguerite-Marie Alacoque or of Madame Guyon.

${ }^{94}$ Science, 149.

${ }^{95}$ Such a comparison is explicitly evoked by Surin in Science, 190 with reference to Manichaeism.

96 'Venite ad me, omnes qui laboratis et onerati estis, et ego reficiam vos, dicit Dominus. Panis, quem ego dabo, caro mea est, pro mundi vita. Accipite et comedite: hoc est corpus meum, quod pro vobis tradetur. Hoc facite in meam commemorationem. Qui manducat carnem meam, et bibit meum sanguinem, in me manet, et ego in illo. Verba quæ ego locutus vobis spiritus et vita sunt.'

${ }^{97}$ Imitation, IV, Preface. 


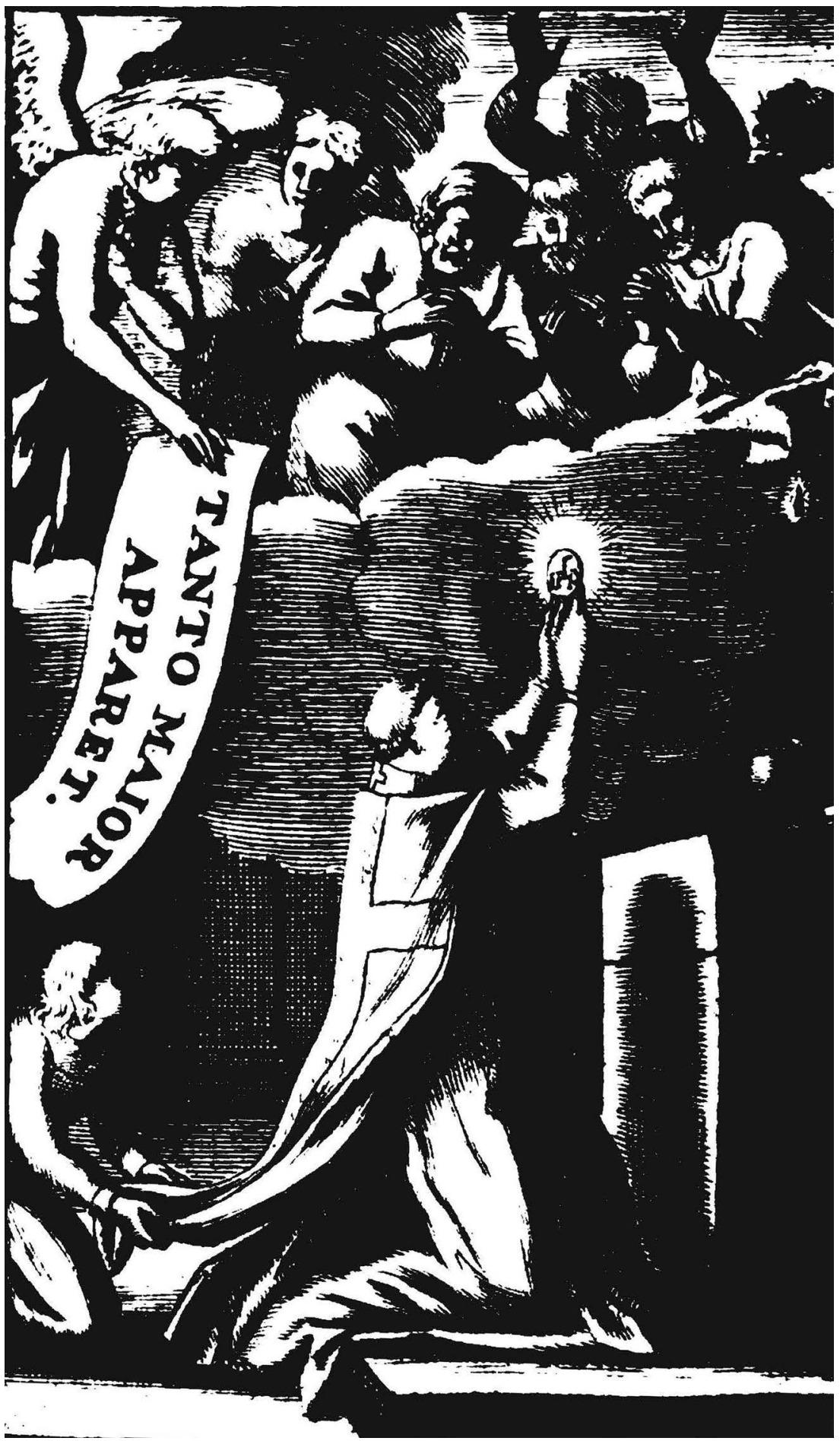

Figure 9. L'abaissement de Jésus-Christ dans le St Sacrement est une marque de sa grandeur. 
est fait' ${ }^{98}$ ('Your word in times gone by did everything instantly, | So that nothing separated the sound from the effect; | And [now] by your power passing to secondary causes, | Scarcely has man spoken, than your will is done'). It has as a result, and in conformity with the title of the work, the effect of transforming the doctrinal understanding of the Eucharist as 'anamnesis', or recollection, into one that is also related to the process of 'mimesis', or imitation. ${ }^{99}$ Furthermore, the improbability of this promise is both implicitly recognised and empirically disregarded in the fourth stanza of the first chapter, once again entirely invented by the poet: 'Un pauvre, un mendiant s'en voir par toi pressés! | S'y voir par toi repus de ton corps adorable! | Mais enfin tu l'as dit, Seigneur, et c'est assez'100 ('A poor man or a beggar see themselves urged to [make their communion] by you!| They see their hunger satisfied by you as they receive your adorable body! | But in the end you said it, Lord, and that is enough'), a conviction that is taken up later in the same book as a devotional focus in the credo of the addressee: 'Je crois, et je suis prêt de signer de mon sang, | Que sous ce rond, que sous ce blanc, | Véritable Homme-Dieu, tu caches ta présence'101 ('I believe, and I am ready to sign with my blood, | That beneath this white disc, | True Man-God, you conceal your presence').

But this emphasis also brings us, predictably enough in the period, into another area of difficulty, and so into the domain of polemic. The dispute surrounding the Real Presence had been played out between the Roman Church and its Calvinist adversaries in many forms during and since the defining years of the Reformation even if, in the exchange I shall consider here, the issues in dispute seem to have remained within the formats of scholarly disagreement; and the principal figure of the French Counter-Reformation to have embarked on a defence of the Real Presence, equally unsurprisingly, is Bossuet, in one of his earliest didactic publications, the Exposition de la doctrine catholique of $1655 .{ }^{102}$ The Exposition is written in reply to a Protestant Catechism by the Reformed minister in Metz (where Bossuet was a deacon), Paul Ferry, ${ }^{103}$ and, at least in the first instance (and unusually for the genre), seeks to establish an irenic tone. Nonetheless, although Bossuet's apologia deals with the whole gamut of issues which divided the two confessions, the dispute concerning

\footnotetext{
${ }^{98}$ Imitation, IV, 2.

${ }^{99}$ Such a reassurance is in turn a poetic variant on the traditional Catholic formula of ex opere operantis ecclesia, whereby the simple act of pronouncing the words of institution, by a validly ordained priest, effects the transubstantiation of the elements of bread and wine into the Body and Blood of Christ. See Figure 9.

${ }^{100}$ Imitation, IV, 1. Cf. Ibid., 5.

${ }^{101}$ Imitation, IV, 4 ('Et vere credo quia tu præsens ex his in sacramento, Deus et homo').

102 Exposition de la doctrine de l'église catholique sur les matières de controverse, in Bossuet (1875a), Vol. XIII, 1-105.

${ }^{103}$ Catéchisme général de la réformation de la religion, Sedan, 1654.
} 
the Real Presence is, in his words, "la plus importante et la plus difficile de nos controverses, et celle où nous sommes en effet le plus éloignés' ${ }^{104}$ ('the most important and the most difficult of all our controversies, and the one in which we are in effect the furthest apart'). The Exposition is then amplified in turn by the far more ambitious, if incomplete, Fragments sur l'Exposition, written after Bossuet had become Bishop of Meaux in 1671, but unpublished until $1753 .{ }^{105}$ These are in turn a reply to two reactions to the treatise: one, only briefly quoted, by a certain David Noguier in $1673,{ }^{106}$ and the other, published in the same year and providing the principal polemical intertext, by an anonymous figure supported by the Protestant community at Charenton, and identified as one Marc-Antoine de la Bastide, who died in London in 1704. ${ }^{107}$

The issue, as it is expressed in the unilateral terms of Bossuet's apologia, is simply presented as being predicated on the impossibility of a compromise between the belief, on the one hand, that 'nous [savons] par la foi que [le Fils de Dieu] est présent' ('we [know] by faith that the [Son of God] is present'), for the Roman Church, as against '[le Fils de Dieu] est présent par la foi' ('[the Son of God] is present by faith'), for Calvinism. ${ }^{108}$ Or, helpfully amplifying the two positions in the Fragments: in the first, reflecting Catholic teaching: '[Le] corps de Jésus-Christ [descend] dans le sacrement pour y être réellement présent' ('[The] body of Christ [comes down] into the sacrament so as to be really present in it'); in the second - that preferred by the Calvinist persuasion, and based above all on the dogma of the Ascension: '[Nous] disons seulement que par la foi nous élevons nos cœurs au ciel, où il est; et que c'est ainsi que nous participons à Jésus-Christ très réellement, mais spirituellement' ${ }^{\prime 109}$ ('[We] simply say that by faith we raise our hearts to heaven, where he is; and it is in this way that we participate in Christ, very really but spiritually') (this is alongside other terms attributed to Calvinists such as 'présence morale' ('moral presence'), 'présence mystique' ('mystical presence') or 'présence d'objet et de vertu' ('material and virtual presence')). ${ }^{110}$

${ }^{104}$ Exposition, 85.

${ }^{105}$ Quatrième fragment : Sur l'Eucharistie, in Fragments relatifs à l'Exposition in Bossuet (1875b), Vol. XIII, 121-349 (200-326).

${ }^{106}$ Noguier, David, Réponse au livre de Monsieur de Condom, intitulé L'Exposition de la doctrine catholique sur les matières de controverse, Orange, 1673.

107 Réponse au livre de Monsieur de Condom qui a comme titre L'Exposition de la doctrine catholique, Rouen, 1673. Bossuet had briefly served as Bishop of Condom before his translation to Meaux.

${ }^{108}$ Exposition, 79. Other Eucharistic issues are also explored at length, such as, most obviously, the status of the Mass as sacrifice, as against the apparent counter-claim in the Letter to the Hebrews X, 11-18. Bossuet's phrase proposes that the purpose of the Mass relative to Christ's own sacrifice is to 'célébrer la mémoire de sa mort et s'en appliquer la vertu' ('celebrate the memory of his death and apply its power to ourselves') (Fragments, 275).

${ }^{109}$ Fragments, 222.

${ }^{110}$ Fragments, 219. 
The initial strategy adopted by Bossuet in reply to Reformed teaching, and consistent with the ostensible tenor of his work, is to lay the emphasis on simplicity and (apparent) common sense (which is also a frequent point of reference of polemic in the period). This approach also both leads into - and accords perfectly with - the superficially plausible claim that the Catholic church does no more than understand the words of institution au pied de la lettre, and that '[il] ne nous faut non plus demander pourquoi nous nous attachons au sens propre et littéral, qu'à un voyageur pourquoi il suit le grand chemin'"111 ('[there] is no more reason to ask us why we stick to their clear and literal meaning, than to ask a traveller why he follows the main highway'). This claim is made all the more solid in that the Gospel nowhere affords a metaphorical marker for, or amplification of, the words of institution. In more scholarly support of such an attractively common-sense reading, Bossuet then evokes salvation history, first in terms of the (albeit contrary) accomplishment of Jewish precedent; and then in terms of divine authority, whereby the apparent inconsistency of the sacrament with the visible nature of what is consumed is justified by the omnipotent nature of the divine speaker (who was equally able to say 'Woman, you are healed"112 or 'Your son is alive'113). Here again he echoes, more prosaically, the Cornelian paraphrase, whereby 'les paroles toutes-puissantes du Fils de Dieu opèrent

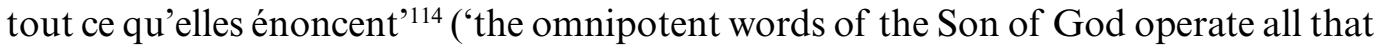
they enunciate'). Or, in a synthesis now afforded by the Fragments, 'loin de forcer les paroles de l'Écriture Sainte pour l'accommoder à notre raison [. . .], nous croirons plutôt que le Fils de Dieu forcera par sa puissance infinie toutes les lois de la nature, pour vérifier ses paroles dans leur intelligence la plus naturelle"115 ("far from forcing the words of Holy Scripture in order to accommodate it to our reason [. . . ] we shall prefer to believe that the Son of God will force by his infinite power all the laws of nature, so as to endorse his words in their most natural understanding').

But asserting that words simply mean what they appear to mean looks, or is, disingenuous, and is certainly polemically fragile; and Bossuet is therefore driven above all in the Fragments to establish a hermeneutic framework, or in his own term un principe, since the interpretation of the single phrase of institution must also be understood in the context of scriptural precedent, in support of which he cites the Biblical evidence that, in the Old Testament, Moses's rod became a snake, ${ }^{116}$ and that, at the

\footnotetext{
111 Exposition, 74.

112 Luke 13:12.

113 John 4:50.

${ }^{114}$ Exposition, 87. Cf. Fragments, 210.

${ }^{115}$ Fragments, 210.

${ }^{116}$ Exodus 4:3.
} 
wedding feast at Cana, the first of the Gospel miracles, the water became wine. ${ }^{117}$ There is also a moment of quiet irony here, as Bossuet rejects the hypothesis whereby '[Jésus-Christ] aurait conservé l'eau et le vin' ('[Christ] might have preserved the water and the wine') in favour of the clear Biblical indication 'qu'il aurait changé l'eau en vin' ('that he changed the water into wine'), before making the analogy explicit: '[Ainsi], quand il prononce en termes précis que ce qu'il présente c'est son corps, il ne faut pas entendre qu'il mêle son corps avec le pain, mais seulement qu'il change le pain en son corps' ${ }^{\prime 118}$ ('[Thus], when he pronounces in precise terms that what he presents us with is his body, it should not be understood that he mixes his body with the bread, but simply that he changes the bread into his body').

If the words of institution are, as a result, to be understood literally, such a reading is in turn supported by a powerful Biblical metaphor, that of the Christic marriage, as developed at length in Ephesians 5:21-33: 'Jésus-Christ [. . .]', Bossuet argues as a result, 'a donné à ses fidèles un droit réel sur son corps, et [. . .] l'a mis en leur puissance d'une manière qui n'en est pas moins réelle, pour n'être connue que par la foi'"19 ('Christ [. . . ] has given his faithful a real right over his body, and [. . .] has placed it in their power in a way that is none the less real for only being recognised by faith'), so that the Church in this respect enjoys nothing less than 'le droit de l'épouse' ('the right of the bride') (a right that is also claimed, as we have seen, by such virgin martyrs as Lucy, Cecilia and indeed Theodora). It is in this by virtue of the literal understanding of the words of institution, he paradoxically argues, that the Scriptural metaphor is accorded its full potency. But another principe has now to be tacitly accorded as a result, since such a degree of hermeneutic flexibility can only be admitted within the context of a semantic hierarchy determined not now by common sense, but by tradition and authority. Finally, the global conclusion to the remarks is found in Bossuet's distinction between theology and philosophy, so that, now in a tripartite epistemology, objections to the Real Presence '[s'accordent] avec la raison humaine et avec les sens' ('[are in conformity] with human reason and with the senses'), whereas Catholic doctrine 's'accorde parfaitement avec elle-même et avec les grands principes du christianisme'120 ('is in conformity with itself and with the great principles of Christianity').

Such an apparent conundrum, however, is bound to bring several other issues of interpretation into focus. First, there is the problematic relationship between signifier and signified, whereby the substance designated does not and cannot correspond to the deictic indicator. This is again developed in the Fragments, where the semiotic status of the words of institution has to be determined since, to put it in Bossuet's

\footnotetext{
${ }^{117}$ Fragments, 249-50. John 2:1-10.

${ }^{118}$ Fragments, 252.

119 Fragments, 319.

${ }^{120}$ Fragments, 201.
} 
phrase, 'tous les signes ne sont pas de même nature"121 ('all signs are not of the same nature'). He then goes further and insists that any amount of semiotic theory will be redundant if the words following the indicator accord to it a literal status, thereby making it, in his terminology, neither a 'signe naturel' ('natural sign'), such as a portrait, nor even a 'signe d'institution' ('institutional sign'), such as a garment or an anniversary, ${ }^{122}$ but rather a literal equivalence, 'une chose inouie [. . .], [dont] on ne peut alléguer aucun exemple" 123 ('something unheard-of [. . .], [of which] no example can be cited') before going on to assert that 'c'est néanmoins ce principe qui tranche la difficulte' 124 ('this is nonetheless the principle which cuts through the difficulty'). Bossuet even manages a moment of probably unconscious humour in attempting an equivalent application of simile in the New Testament. Defending the literal understanding of the words of consecration as against their figurative status preferred by Calvinism, he contrasts them with other parable-centred metaphors (or rather, he would argue, with metaphors tout court), such as Christ as the door or the vine, or God the Father as a labourer. He is thus able to conclude, with deadpan irony, on the logical outcome of such a comparison: 'Cette comparaison peut donner un fondement légitime de dire, sans rien expliquer, toutes les fois qu'on rencontrera une porte, une vigne et un laboureur: Ceci est le Fils de Dieu: [ou] Celui-là est le Père éternel' ${ }^{125}$ ('Such a comparison can give a legitimate justification for saying, without further explanation, each time that you encounter a door, a vine or a worker: This is the Son of God: [or] That man is the eternal Father'). Relatedly, he is witheringly dismissive of the supplementary image of the sun as an approximation to the relative degree of presence in the Blessed Sacrament as expressed in the Basel Confession. ${ }^{126}$ According to this, in Bossuet's paraphrase: 'Jésus-Christ [. . .] n'est pas absent de son Église lorsqu'elle célèbre la Cène. Le soleil, quoique absent de nous, étant dans le ciel, néanmoins nous est présent efficacement: combien plus le soleil de justice Jésus-Christ, quoiqu'il soit absent de nous, étant dans le ciel, nous est présent, non corporellement, mais spirituellement par son opération vivifiante' ${ }^{127}$ ('Christ [ . . ] is not absent from his Church when she celebrates the Last Supper. The sun, although absent from us, since it is in the sky, is nonetheless present to us effectively: how much more the sun of justice, Jesus Christ, although absent from us, being in the heavens, is present to us, not bodily, but spiritually by his enlivening action'). But this image is in turn (and again

\footnotetext{
121 Fragments, 301.

122 Fragments, 304.

123 Fragments, 302.

124 Fragments, 304.

125 Fragments, 303.

126 This document (1534) articulates one of the many variants of Reformed teaching on the question.

127 Fragments, 219-20.
} 
typically of polemic) held up to ridicule on account of its ingenuity and complexity, as against the simplicity of the dogma of the Real Presence.

The consistent point of negative comparison in such arguments in both works is the reformed tradition of Socinianism, with the stress allegedly placed by its founders on the absence of likelihood within the whole theology of the Incarnation. ${ }^{128}$ But this too is put to polemical advantage, since Bossuet is able to insist that the Eucharistic transformation is better interpreted as a kind of synecdoche of the literal and nonfigurative nature of the Incarnation and Passion ('pour nous certifier que nous avons part à son sacrifice et à la réconciliation du genre humain' ('to ensure us that we have a part in his sacrifice and in the reconciliation of the human race'), in Bossuet's formula). ${ }^{129}$ In this way, he insists, "la manducation de notre victime doit être aussi réelle à la Sainte Table, que son immolation a été réelle à la croix"130 ('the consumption of our victim must be as real at the Holy Table, as his immolation was real on the Cross') even if how this happens is a mystery whose full extent has not been revealed to humankind, and the mode of whose operation, in his phrase, 'dépend de l'entière compréhension de la vérité, que Dieu nous a réservée pour la vie future'131 ('depends on a full understanding of the truth, which God has kept back from us until the life to come').

Finally, the dogma is asserted in distinction to the predominantly symbolic nature of baptism on the one hand and the pedagogic nature of preaching on the other. In this way, the three different modes of Christian engagement are put forward in the Fragments as initiation, education and fulfilment (baptism, preaching and Eucharist). As a result of their failure to make this distinction, Bossuet asserts, Calvinists find themselves situated between Roman orthodoxy and secular thinking: 'Quand on s'attache ou tout à fait à la foi [ . . .] ou tout à fait à la raison humaine [ . . .] on peut établir une suite et faire comme un plan de doctrine. Mais quand on veut faire un composé de l'un et de l'autre [...] on tombe dans des opinions dont les seules contrariétés font voir la fausseté toute manifeste'132 ('When you attach yourself either entirely to faith, [...] or entirely to human reason, [...] you can establish an outcome and draw up, as it were, a doctrinal agenda. But when you try and combine them [...], you fall into opinions whose very contradictions make you see their manifest error'). But they also find themselves caught between Roman orthodoxy and those primitive heresies which

${ }_{128}$ The term originates in the names of two Italian religious teachers of the mid-16th century called Soz[z]ini, and approximates to Unitarianism by denying the literal doctrine of the Incarnation and, relatedly, that of the Trinity. It is the subject of the seventh of Voltaire's Lettres philosophiques.

${ }^{129}$ Exposition, 82.

${ }^{130}$ Fragments, 215.

131 Fragments, 204.

${ }^{132}$ Exposition, 85. 
were resolved in the early Church - to which resolution Calvinists give assent. This now enables Bossuet, once again in a spirit of (at least rhetorical) harmony, to evoke as a point of shared opposition 'les anciens hérétiques, que les prétendus réformés détestent, aussi bien que nous' ${ }^{133}$ ('the early heretics, which the so-called reformed [religions] hold in scorn, just as much as we do'). It is in this light that he is able to ask why, when the Calvinists accept the non-Biblical neologism of consubstantiality of Father and Son, as articulated at the Council of Nicaea, they now feel compelled to reject the neologism of transubstantiation as formulated at the Council of Trent. ${ }^{134}$ In all these ways, therefore, a hermeneutic is established whereby the extent of referential authority required to interpret Scripture must be dependent on something beyond human reason or, in Bossuet's term, must be the result of 'une lumière plus haute'135 ('a higher degree of enlightenment').

In all this area of controversy, therefore, Bossuet drives the reader into a whole range of exegetical difficulties. Where this polemic differs from many others in the period is in its purported aim to convince and convert, and in its very extensive use of concession in the process. Where it seems weak, paradoxically, is in its tendency to accumulate categories of argument (thus common sense, semiotics, hermeneutics, tradition and authority), rather than limit itself to a single domain of demonstration. The synthesis which concludes the Fragments nevertheless re-introduces a tone of both simplicity and extensibility, as Bossuet evokes 'un merveilleux enchaînement des mystères du christianisme' ('a wonderful coherence in the mysteries of Christianity'), linking together as they do 'la simplicité de la lettre, l'impact du sens naturel et l'implication d'un tel mystère' ('the simplicity of the letter, the impact of the natural meaning and the implication of such a mystery'). And, as if to illustrate this potential, he re-introduces a startlingly physical reprise of St Paul's erotic metaphor, in a formula which is only capable of being realised by the terms of the Catholic doctrine of the Real Presence: 'Jamais l'Église n'entend mieux combien l'Époux est à elle', Bossuet writes, 'ni ne s'y attache avec plus d'ardeur, que lorsqu'elle jouit de son corps sacré'136 ('Never does the Church better understand how fully the Spouse is wedded to her, nor attaches himself to her with more fervour, than when she rejoices in his sacred body'). It is thus once again through literal imitation, in this understanding at least, that the Church arrives at spiritual consummation.

What I have been trying to suggest in the four texts which I have chosen to explore (not quite at random, and from a vast corpus of material) is that the issues thrown up

\footnotetext{
133 Fragments, 217.

${ }^{134}$ A further distinction is also made with Lutherans, who subscribe to the doctrine of the Real Presence, but stop short at the practice of adoration (Fragments, 264).

${ }^{135}$ Fragments, 204.

${ }^{136}$ Fragments, 325.
} 
by Christic imitation and its written manifestations in the period are of themselves a source of enquiry and experiment to those writers who address them, in poetry, drama, autobiography and polemic. If the lived imperative to imitate Christ persists as the unrealisable ideal of the key text of devotio moderna, it would seem that neither its written transmission onto the page and the stage, nor its empirical realisation in diabolic exorcism, nor indeed its sacramental enactment in liturgy is any more straightforward. 'Dites ce que je dis pour faire comme moi'-'Say what I say in order to do what I do'-is Corneille's version. That is easier said than done. Or perhaps, at least on the evidence of this material, it is easier done than said.

$$
* * *
$$

Several generic categories are absent from my sample: those, most obviously, of lyric poetry and pulpit oratory; but also of apologetics, catechetics and the biblical epic. What I have nonetheless tried to foreground are some of the ways in which the enactment of Christ's example in the Catholic tradition poses difficulties to those writers who translate it, dramatise it, record it or defend it. All four modes of interaction with the specifics of the Incarnation lead us through questions of theology to questions of ethics and aesthetics and, ultimately, to questions of form and language. How to translate the economy of an already remote Latin text into the idioms and rhythms of the vernacular; how to represent on the neo-classical stage the ordeals which marked the early Church, and to elicit the admiration - the sense of astonishment-which it is their business to evoke in an audience; how to convey in an autobiographical document a sequence of experiences whose gruesome intensity alienates the retrospective recorder from his own earlier self; and how to account, by means of argument, for a dogma which by definition transcends those same epistemological categories to which an appeal is bound to be made. The perception of the post-Tridentine Roman Church as an earthly manifestation of monolithic certainty is nowhere more challenged than in the written legacy of the French 17th century, the extent and range of whose problematics transform those very difficulties into the fertile material of theological enquiry, of spiritual renewal and of literary creativity.

\section{REFERENCES}

Barthes, Roland (1971), Sade, Fourier, Loyola (Paris, Seuil (Points)).

[Bastide, Marc-Antoine de la] (1673), Réponse au livre de Monsieur de Condom qui a comme titre L'Exposition de la doctrine catholique (Rouen, Jean Lucas).

Bossuet, Jacques-Bénigne (1875a), Exposition de la doctrine de l'église catholique sur les matières de controverse, in F. Lachat (ed.), Euvres complètes, Vol. XIII (Paris, Louis Vivès), 1-105.

Bossuet, Jacques-Benigne (1875b), Quatrième fragment: Sur l'Eucharistie, in Fragments relatifs à l'Exposition in Bossuet, in F. Lachat (ed.), Euvres complètes, Vol. XIII (Paris, Louis Vivès), 121-349 (200-326). 
Bossuet, Jacques-Bénigne (1961), Panégyrique de Saint Joseph, in Abbé B. Velat \& Yvonne Champailler (eds), Euvres (Paris, Gallimard (Bibliothèque de la Pléiade)), 327-48.

Corneille, Pierre (1656), De l'Imitation de Jésus-Christ (Rouen, Robert Ballard).

Corneille, Pierre (1862-8a), De l'Imitation de Jésus-Christ, in M. Ch. Marty-Laveaux (ed.), CEuvres complètes, Vol. VIII (Paris, Hachette (Grands Écrivains de la France)).

Corneille, Pierre (1862-8b), Théodore, vierge et martyre, tragédie chrétienne, in M. Ch. Marty-Laveaux (ed.), Euvres complètes, Vol. V (Paris, Hachette (Grands Écrivains de la France)), 1-111.

Corneille, Pierre (1963a), L'Imitation de Jésus-Christ, in André Stegmann (ed.), Euvres complètes (Paris, Seuil (L'Intégrale)), 905-1046.

Corneille, Pierre (1963b), Théodore, vierge et martyre, tragédie chrétienne, in André Stegmann (ed.), Euvres complètes (Paris, Seuil (L'Intégrale)), 391-493.

Corneille, Pierre (1984a), De l'Imitation de Jésus-Christ, traduite et paraphrasée en vers français, in Georges Couton (ed.), CEuvres complètes, 3 vols (Paris, Gallimard (Bibliothèque de la Pléiade)), II, 785-1182.

Corneille, Pierre (1984b), Discours des trois unités, in Georges Couton (ed.), CEuvres complètes, 3 vols (Paris, Gallimard (Bibliothèque de la Pléiade)), III, 174-90.

Corneille, Pierre (1984c) Examen de Nicomède, in Georges Couton (ed.), Cuvres complètes, 3 vols (Paris, Gallimard (Bibliothèque de la Pléiade)), II, 641-4.

Corneille, Pierre (1984d) Lettres au Père Boulart, in Georges Couton (ed.), Euvres complètes, 3 vols (Paris, Gallimard (Bibliothèque de la Pléiade)), II, 1193-1202.

Corneille, Pierre (1984e), Théodore, vierge et martyre, tragédie chrétienne, in Georges Couton (ed.), Euvres complètes Couton (Paris, Gallimard, 3 vols (Bibliothèque de la Pléiade)), II, 267-343 and Notice at $1312-31$.

D’Aubignac, François d'Hédelin, abbé (2001), La pratique du théâtre, ed. Hélène Baby (Paris, Honoré Champion (Sources Classiques)).

Ferry, Paul (1654), Catéchisme général de la réformation de la religion (Sedan).

François de Sales, St (1969), Traité de l'amour de Dieu, in André Ravier and Roger Devos (eds.) CEuvres (Paris, Gallimard (Bibliothèque de la Pléiade)), 319-972.

Ignatius Loyola, St (2004), The Spiritual Exercises, trans. Michael Ivens (Leominster, Gracewing).

Lejeune, Philippe (1971), L'Autobiographie en France (Paris, Armand Colin). PMCid:PMC1796103

Noguier, David (1673), Réponse au livre de Monsieur de Condom, intitulé L'Exposition de la doctrine catholique sur les matières de controverse (Orange, Édouard Raban).

Pascal, Blaise (2004), Les Provinciales, Pensées et Opuscules divers, ed. Philippe Sellier \& Gérard Ferreyrolles (Paris, Pochothèque).

Surin, Jean-Joseph (1990), Triomphe de l'amour divin sur les puissances de l'enfer et Science expérimentale des choses de l'autre vie, suivi de Les aventures de Jean-Joseph Surin, par Michel de Certeau (Grenoble, Jérôme Millon). PMCid:PMC330987

Torri, A. (1855), Della Imitazione di Gesù Christo (Florence, F. Le Monnier).

Voltaire (1957), 'Catalogue de la plupart des écrivains français', in Le Siècle de Louis XIV, in René Pomeau (ed.), Euvres historiques (Paris, Gallimard (Bibliothèque de la Pléiade)), 603-1274.

Voltaire (1974-5), Commentaires sur Corneille II, in David Williams (ed.), CEuvres complètes, Vol. 54 (Oxford, Voltaire Foundation), 457-75. PMid:5559368

The author: Richard Parish is a Professor of French in the University of Oxford and a Fellow of St Catherine's College. He has published principally on 17th-century theatre (Racine: the limits of tragedy, 1993) and Catholic writing (Catholic particularity in seventeenth-century French writing: Christianity is strange, 2011, based on the 
Bampton Lectures delivered in Oxford in 2009), as well as editing Voltaire and Condorcet's Éloge et Pensées de Pascal for the Voltaire Foundation in 2008. He is currently beginning a project on the Mémoires of the duc de Saint-Simon.

Contact: richard.parish@stcatz.ox.ac.uk

This article is licensed under a

Creative Commons Attribution-NonCommercial-NoDerivs 3.0 Unported License.

Journal of the British Academy (ISSN 2052-7217) is published by

The British Academy - the national academy for the humanities and social sciences.

10-11 Carlton House Terrace, London, SW1Y 5AH

www.britishacademy.ac.uk 